Prepared in cooperation with the

U.S. Department of Homeland Security-Federal Emergency Management Agency

\title{
Simulated and Observed 2010 Floodwater Elevations in the Pawcatuck and Wood Rivers, Rhode Island
}

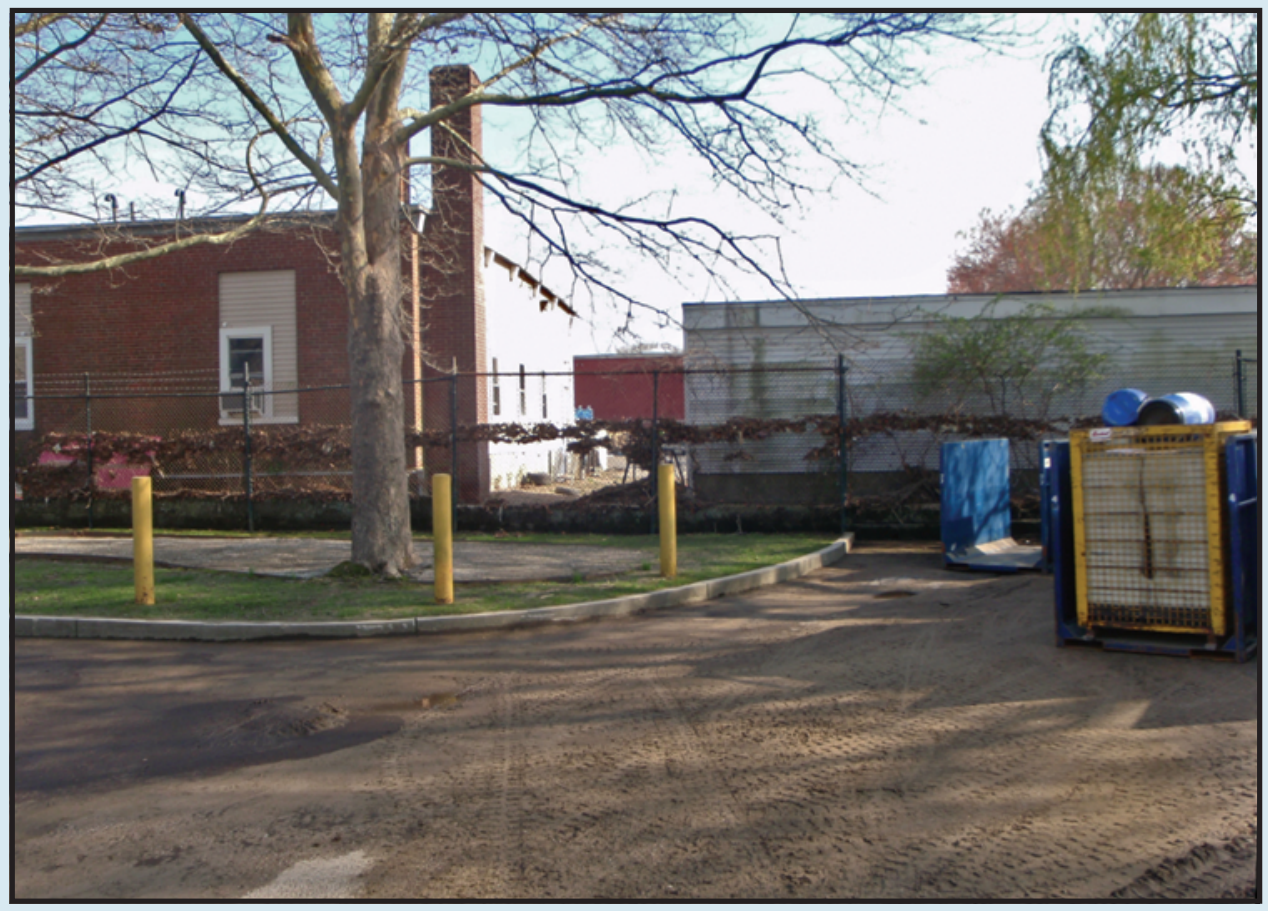

Scientific Investigations Report 2013-5193 
Front cover. Photograph of high-water debris on fence near U.S. Geological Survey streamgage at Pawcatuck River at Westerly (0118500), Rhode Island. 


\section{Simulated and Observed 2010 Floodwater Elevations in the Pawcatuck and Wood Rivers, Rhode Island}

By Phillip J. Zarriello, David E. Straub, and Thor E. Smith

Prepared in cooperation with the

U.S. Department of Homeland Security-Federal Emergency Management Agency

Scientific Investigations Report 2013-5193 


\title{
U.S. Department of the Interior SALLY JEWELL, Secretary
}

\section{U.S. Geological Survey \\ Suzette M. Kimball, Acting Director}

\author{
U.S. Geological Survey, Reston, Virginia: 2014
}

For more information on the USGS - the Federal source for science about the Earth, its natural and living resources, natural hazards, and the environment, visit http://www.usgs.gov or call 1-888-ASK-USGS.

For an overview of USGS information products, including maps, imagery, and publications, visit http://www.usgs.gov/pubprod

To order this and other USGS information products, visit http://store.usgs.gov

Any use of trade, firm, or product names is for descriptive purposes only and does not imply endorsement by the U.S. Government.

Although this information product, for the most part, is in the public domain, it also may contain copyrighted materials as noted in the text. Permission to reproduce copyrighted items must be secured from the copyright owner.

Suggested citation:

Zarriello, P.J., Straub, D.E., and Smith, T.E., 2014, Simulated and observed 2010 floodwater elevations in the Pawcatuck and Wood Rivers, Rhode Island: U.S. Geological Survey Scientific Investigations Report 2013-5193, 24 p., http://dx.doi.org/10.3133/sir20135193. 


\section{Contents}

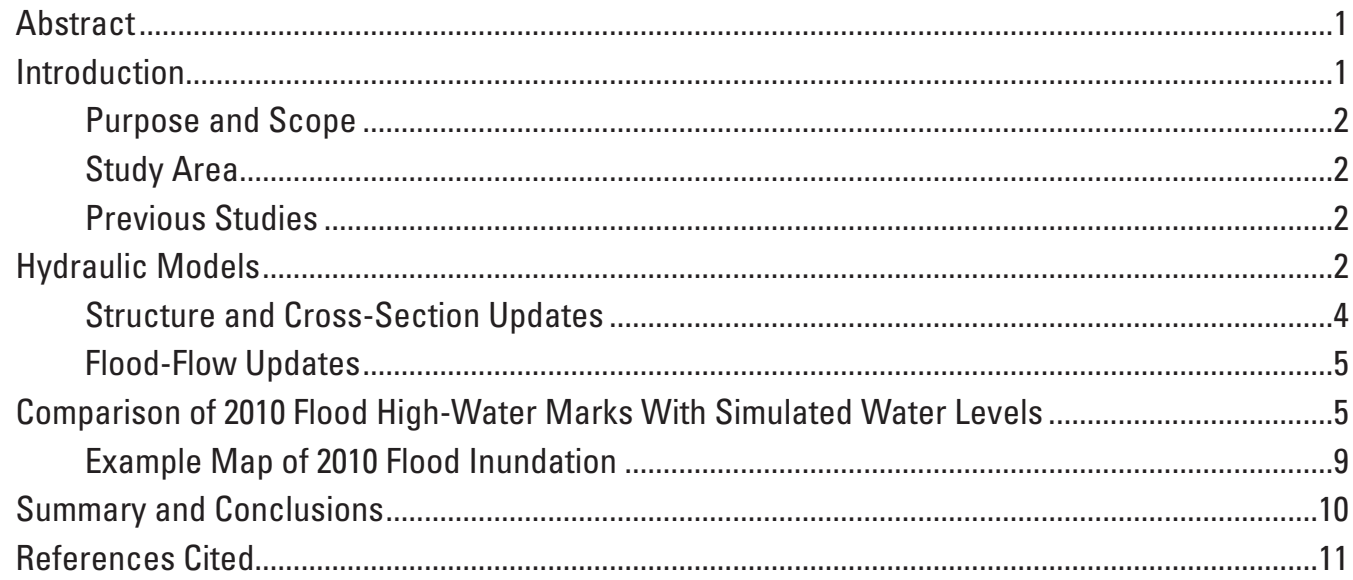

Appendix 1. Pawcatuck River and Wood River Hydraulic Models: Technical Support Data Notebook

\section{Figures}

1. Map showing Pawcatuck River Basin and reaches with detailed hydraulic analysis, Rhode Island

2. Map showing high-water marks obtained after the 2010 flood along reaches of detailed hydraulic analysis for the Pawcatuck and Wood Rivers, Rhode Island

3. Graphs showing differences between the 2010 flood high-water mark (HWM) elevations and simulated water-surface elevations from the effective flood insurance study (FIS) and the updated hydraulic model for the 0.2-percent annual exceedance probability flows for Rhode Island.

4. Boxplot showing difference between the simulated hydraulic model 0.2-percent annual exceedance probability water-surface elevations and the observed 2010 flood high-water mark (HWM) elevations in the Pawcatuck and Wood Rivers, Rhode Island

5. Map showing flood inundation and depth of flooding at the 0.2-percent annual exceedance probability along the Pawcatuck River near the streamgage in Westerly, Rhode Island.

6. Photograph showing the high-water line on the fence following the March-April 2010 flood near the streamgage on the Pawcatuck River at Westerly (01118500), Rhode Island 


\section{Tables}

1. Reaches in the Pawcatuck River Basin where detailed hydraulic analyses were done

2. Summary of structures surveyed, the number of structures represented, and total number of cross sections in the hydraulic models of the Pawcatuck and Wood Rivers, Rhode Island.

3. Comparison of effective flood insurance study and updated flood flows in the Pawcatuck and Wood Rivers, Rhode Island.

4. Comparison of the effective flood insurance study (FIS) and updated hydraulic model water-surface elevations for the 0.2 -percent annual exceedance probability flows to the 2010 flood high-water mark (HWM) elevations along the Pawcatuck and Wood Rivers, Rhode Island

\section{Conversion Factors, Datum, and Abbreviations}

Inch/Pound to SI

\begin{tabular}{lcl}
\hline \multicolumn{1}{c}{ Multiply } & By & \multicolumn{1}{c}{ To obtain } \\
\hline foot $(\mathrm{ft})$ & Length & \\
mile $(\mathrm{mi})$ & 0.3048 & meter $(\mathrm{m})$ \\
& 1.609 & kilometer $(\mathrm{km})$ \\
\hline square mile $\left(\mathrm{mi}^{2}\right)$ & Area & \\
\hline & 259.0 & hectare $(\mathrm{ha})$ \\
\hline cubic foot per second $\left(\mathrm{ft}^{3} / \mathrm{s}\right)$ & Flow rate & \\
\hline
\end{tabular}

Vertical information is referenced to North American Vertical Datum of 1988 (NAVD 88).

Horizontal coordinate information is referenced to North American Datum of 1983 (NAD 83).

Elevation, as used in this report, refers to distance above the vertical datum. 


\section{Abbreviations}

$\begin{array}{ll}\text { AEP } & \text { annual exceedance probability } \\ \text { DFIRM } & \text { digital flood insurance rate map } \\ \text { FEMA } & \text { Federal Emergency Management Agency } \\ \text { FIS } & \text { flood insurance study; effective FIS is the latest FIS approved by FEMA } \\ \text { GIS } & \text { geographic information system } \\ \text { GPS } & \text { global positioning system } \\ \text { HEC-GeoRAS } & \text { geographic support tool for HEC-RAS } \\ \text { HEC-RAS } & \text { Hydrologic Engineering Center-River Analysis System } \\ \text { HWM } & \text { high-water mark } \\ \text { LiDAR } & \text { light detection and ranging } \\ \text { NGTOC } & \text { National Geospatial Technical Operations Center } \\ \text { NHD } & \text { National Hydrography Dataset } \\ \text { TSDN } & \text { Technical Support Data Notebook } \\ \text { USACE } & \text { U.S. Army Corps of Engineers } \\ \text { USGS } & \text { U.S. Geological Survey } \\ \text { WSE } & \text { water-surface elevation }\end{array}$


THIS PAGE INTENTIONALLY LEFT BLANK 


\title{
Simulated and Observed 2010 Floodwater Elevations in the Pawcatuck and Wood Rivers, Rhode Island
}

\author{
By Phillip J. Zarriello, David E. Straub, and Thor E. Smith
}

\section{Abstract}

Heavy, persistent rains from late February through March 2010 caused severe flooding that set, or nearly set, peaks of record for streamflows and water levels at many longterm U.S. Geological Survey streamgages in Rhode Island. In response to this flood, hydraulic models of Pawcatuck River (26.9 miles) and Wood River (11.6 miles) were updated from the most recent approved U.S. Department of Homeland Security-Federal Emergency Management Agency flood insurance study (FIS) to simulate water-surface elevations (WSEs) for specified flows and boundary conditions. The hydraulic models were updated to Hydrologic Engineering Center-River Analysis System (HEC-RAS) using steadystate simulations and incorporate new field-survey data at structures, high resolution land-surface elevation data, and updated flood flows from a related study.

The models were used to simulate the 0.2-percent annual exceedance probability (AEP) flood, which is the AEP determined for the 2010 flood in the Pawcatuck and Wood Rivers. The simulated WSEs were compared to highwater mark (HWM) elevation data obtained in a related study following the March-April 2010 flood, which included 39 HWMs along the Pawcatuck River and 11 HWMs along the Wood River. The 2010 peak flow generally was larger than the 0.2-percent AEP flow, which, in part, resulted in the FIS and updated model WSEs to be lower than the 2010 HWMs. The 2010 HWMs for the Pawcatuck River averaged about 1.6 feet (ft) higher than the 0.2-percent AEP WSEs simulated in the updated model and $2.5 \mathrm{ft}$ higher than the WSEs in the FIS. The 2010 HWMs for the Wood River averaged about $1.3 \mathrm{ft}$ higher than the WSEs simulated in the updated model and $2.5 \mathrm{ft}$ higher than the WSEs in the FIS. The improved agreement of the updated simulated water elevations to observed 2010 HWMs provides a measure of the hydraulic model performance, which indicates the updated models better represent flooding at other AEPs than the existing FIS models.

\section{Introduction}

Heavy, persistent rains from late February through March 2010 caused severe flooding that set, or nearly set, record streamflows and water levels, causing a state of emergency to be declared in many communities in Rhode Island. On March 31, 2010, a statewide Presidential Disaster Declaration (EM-3311; http://www.fema.gov/disasters/3311) was made that affected the emergency recovery operations in all counties in Rhode Island. The flood was characterized as the worst in 200 years with damages estimated in many millions of dollars. As part of the recovery operations, the U.S. Department of Homeland Security-Federal Emergency Management Agency (FEMA) required analysis of the flood to help assess damages and to minimize future flood damages.

In a related FEMA supported study, flood magnitudes were determined at U.S. Geological Survey (USGS) streamgages and regional flood-flow equations were developed for ungaged sites over a range of annual exceedance probabilities (AEPs) for Rhode Island (Zarriello and others, 2012). The magnitude of floods for different AEPs is an important part of determining flood prone areas and risk assessment. Floods for a given magnitude are simulated through hydraulic models of a river reach that converts flow into water levels along the reach on the basis of the river capacity or conveyance. This information is then used for delineation of flood zones, flood-plain management operations, infrastructure design, and other purposes.

The USGS entered into an agreement with FEMA in August 2010 to document and characterize the MarchApril 2010 flood. As part of the agreement, the USGS updated hydraulic models for selected reaches, which were used to simulate water-surface elevations (WSEs) over a range of AEP flows. The simulated WSEs made with the updated hydraulic models, along with WSEs from the existing flood insurance studies (FISs), were evaluated in comparison to high-water marks (HWMs) from the March-April 2010 flood in the Pawcatuck and Wood Rivers in Rhode Island. The updated hydraulic models are important for post-flood analysis and provide tools for future flood management needs. 


\section{Purpose and Scope}

The purpose of this report is to document the Hydrologic Engineering Center-River Analysis System (HEC-RAS) hydraulic models (Brunner, 2010a, b) that were used to simulate WSEs over a range of AEPs flood flows in the Pawcatuck and Wood Rivers. The WSEs computed with updated models are compared to WSEs reported in the effective FIS (the latest FIS approved by FEMA) and to the March-April 2010 flood HWM elevations, which are estimated to have a 0.2-percent AEP in the Pawcatuck and Wood Rivers.

Hydraulic models were developed for the lower part of the Pawcatuck and Wood Rivers. The appendix of this report provides information similar to FEMA (2011) Technical Support Data Notebook (TSDN) guidelines for documenting hydraulic models for FISs.

\section{Study Area}

The Pawcatuck River Basin covers an area of about 295 square miles $\left(\mathrm{mi}^{2}\right)$ mostly in southeastern Rhode Island and southwestern Connecticut (fig. 1) and includes the $88.4 \mathrm{mi}^{2}$ Wood River subbasin. The lower Pawcatuck River forms the border between Rhode Island and Connecticut and discharges into the Atlantic Ocean at Little Narragansett Bay just south of the City of Westerly, R.I. Hydraulic models were developed for the 26.9 miles (mi) of the lower Pawcatuck River and $11.6 \mathrm{mi}$ of the lower Wood River. The modeled portion of the Pawcatuck River starts near its mouth in Westerly, where the river is non-tidal, and ends at the South Kingston town line. The river is generally low gradient and runs through an urbanized area near its mouth and mostly rural areas east of Westerly. The Wood River model reach starts about 0.7 mi upstream of the confluence with the Pawcatuck River and ends about 500 feet ( $\mathrm{ft}$ ) upstream of Barberville Dam near Arcadia. The river has a low to moderate gradient and generally runs through rural areas.

The Pawcatuck River is mainly in Washington County, Rhode Island, but the downstream reach is bordered to the west by New London County, Connecticut. The modeled portion of the Pawcatuck River runs through the Rhode Island towns of Westerly, Hopkinton, Charlestown, and Richmond, and the Connecticut towns of Stonington and North Stonington. The river forms the boundary between parts of the towns. The modeled part of the Wood River is in Washington County and forms the boundary between the towns of Hopkinton to the west and Richmond to the east.

\section{Previous Studies}

Hydrology and hydraulic analyses for the Pawcatuck River Basin were last updated in the FIS for Washington County (FEMA, 2009). The first community FISs were developed by town or city in the 1970s in response to the National Flood Insurance Act of 1968 and the Flood Disaster
Protection Act of 1973, and updated in various years. The countywide FIS revises and supersedes all previous community FIS reports. Community reports, which were limited in extent to the community boundary, are summarized in the countywide report. Flood flows reported in the 2009 Washington County FIS were developed from Pawcatuck River streamgage peak-flow record analysis at Westerly (01118500) and at Wood River Junction (01117500), or Wood River streamgage peak-flow record analysis at Hope Valley (01118000) and near Arcadia (01117800) for flows in these river reaches, respectively. The analysis was limited to the period of available record at these streamgages at the time the analysis was done.

Flood flows for this study were determined from at-site analysis of the streamgage annual peak-flow records through 2010 and regional-regression equations for estimating flood flows at ungaged sites by Zarriello and others (2012). Estimates of uncertainty of the at-site and regression values are provided and were combined with their respective estimated flood quantiles to improve estimates of flood flows at streamgages.

Following the record March-April 2010 flood, 52 HWMs were obtained by the USGS and U.S. Army Corps of Engineers (USACE) along the modeled reaches in the Pawcatuck and Wood Rivers (Zarriello and Bent, 2011). The HWM elevations were surveyed to North American Vertical Datum of 1988 (NAVD 88). Two HWMs could not be found or were destroyed prior to being surveyed, which limited HWM elevations to 39 sites on the Pawcatuck River and 11 sites on the Wood River. The 2010 flood elevations were compared to simulated WSEs for similar exceedance probability floods reported in the FISs and developed in this study with the updated models.

\section{Hydraulic Models}

Existing hydraulic models for the Pawcatuck and Wood Rivers were updated to HEC-RAS, version 4.1.0 (Brunner, 2010a, b), a one-dimensional hydraulic model. Steadystate flow conditions were simulated for specified flows, boundary conditions, and the river's flow carrying capacity or conveyance. The flows input to the model represent selected AEPs using information and methods developed by Zarriello and others (2012). All WSEs reported in this study are in feet referenced to NGVD 88. The Pawcatuck and Wood River revisions were identified by the Rhode Island Emergency Management Agency, in consultation with FEMA, as priority reaches for updating; the model reaches cover about 38 river miles (table 1; fig. 1).

Input data from existing hydraulic models were obtained from archived (microfiche) files for the Pawcatuck and Wood Rivers from the community FISs. The Pawcatuck River model was converted from HEC-2 (U.S. Army Corps of Engineers, 1991). The Wood River was converted from E431 (Shearman, 1976), a step-backwater hydraulic model in use by the USGS at the time. 


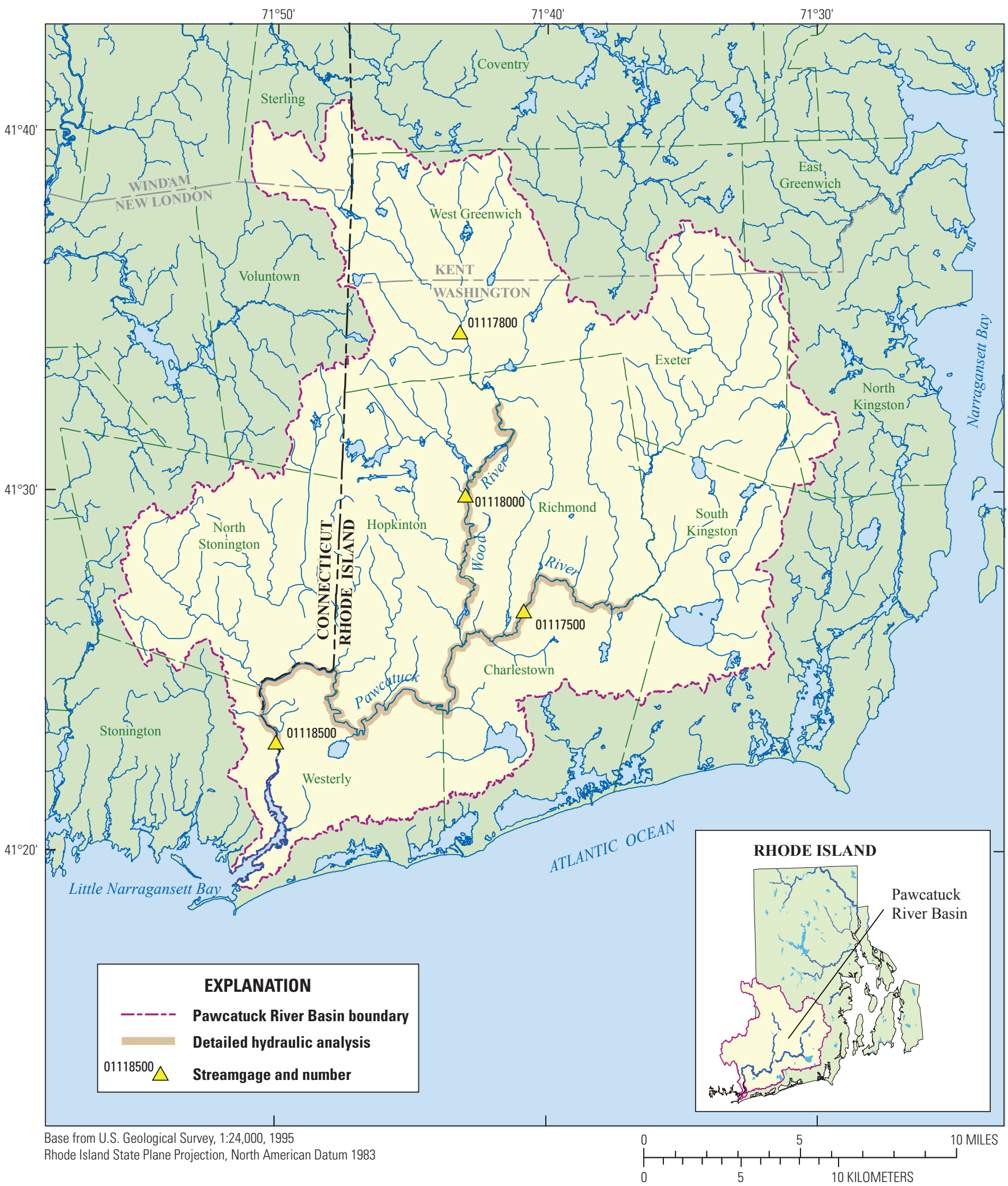

Figure 1. Pawcatuck River Basin and reaches with detailed hydraulic analysis, Rhode Island. 
Table 1. Reaches in the Pawcatuck River Basin where detailed hydraulic analyses were done.

[RI, Rhode Island; CT, Connecticut]

\begin{tabular}{lcll}
\hline Modeled reaches & $\begin{array}{c}\text { Reach length } \\
\text { (miles) }\end{array}$ & \multicolumn{1}{c}{ City or town } & \multicolumn{1}{c}{ County } \\
\hline Pawcatuck River & 26.9 & Westerly, Hopkinton, Charlestown, Richmond & Washington, RI \\
& & $\begin{array}{l}\text { Stonington, North Stonington } \\
\text { Hopkinton, Richmond }\end{array}$ & $\begin{array}{l}\text { New London, CT } \\
\text { Wood River }\end{array}$ \\
\hline
\end{tabular}

\section{Structure and Cross-Section Updates}

Early in the study it became apparent that the existing hydraulic models did not always reflect current conditions; therefore, updated information at structures such as bridges, culverts, and dams, including their channel approaches and exits, were needed to better reflect the current conveyance capacity of the reach. As part of this study, field surveys of channel and structure geometry were obtained at most riverine structures along the modeled reaches, according to FEMA standards for flood-hazard mapping (FEMA, 2011). Field surveys included 11 dams and 23 bridges (table 2). No culverts are present in the modeled reaches. As part of the riverine structural surveys, channel and bank cross sections, and the channel approach to and exit from the structures, were typically surveyed. The new survey information also provided accurate georeferencing of the structures in the updated hydraulic models.

The American Recovery and Reinvestment Act of 2009 provided stimulus funding to a consortium of partners for light detection and ranging (LiDAR) mapping for the coastal northeastern U.S. including all of Rhode Island (accessed December 14, 2012; http://www.neurisa.org/NE_LiDAR Project). This work was coordinated and contracted through the USGS National Geospatial Technical Operations Center (NGTOC), whose contract specifications meet or exceed FEMA standards for hydraulic analysis (Heidemann, 2012).
The NGTOC also provided quality assurance and control of the LiDAR acquisition and interpretation. The LiDAR data provide accurate vertical ground-surface elevation (within $\pm 0.5 \mathrm{ft}$ ) for every pixel nominally spaced every 2 meters $(6.24 \mathrm{ft})$ of land surface in Rhode Island. LiDAR data were not expected to be available in time for this study, but the data for Rhode Island became available in November 2011 when most of the hydraulic model work was in progress. Accordingly, the USGS, in consultation with FEMA, agreed to expand the scope of the study to utilize the newly available data. Cross sections developed from the LiDAR data are georeferenced in the hydraulic models and provide consistency with the land-surface elevation data that are needed to develop accurate flood inundation maps. The LiDAR data also allow additional cross sections to be added where distances between the existing cross sections exceed the recommended standards. The cross sections also could be extended to fully incorporate inundated areas that may have been truncated by the limits of the previous cross section. The limitation of the LiDAR data is that the channel geometry below the water surface had to be interpolated from previous channel crosssection information except where it was determined by the field surveys done during this study. Future revisions to the hydraulic models should consider updating the in-channel cross-section information.

In anticipation that the revised hydraulic models may be later used as part of FEMA's revisions to the National

Table 2. Summary of structures surveyed, the number of structures represented, and total number of cross sections in the hydraulic models of the Pawcatuck and Wood Rivers, Rhode Island.

[Total sections, total number of cross sections in the model]

\begin{tabular}{lcccccc}
\hline \multirow{2}{*}{ Reach } & \multicolumn{2}{c}{ Dams } & \multicolumn{3}{c}{ Bridges } & \multirow{2}{*}{ Total sections } \\
\cline { 2 - 3 } \cline { 6 - 7 } & Surveyed & Modeled & & Surveyed & Modeled & \\
\hline Pawcatuck River & 3 & 5 & & 14 & 26 & 362 \\
Wood River & 9 & 9 & & 9 & 10 & 111 \\
\hline Total & 11 & 14 & 23 & 36 & 473 \\
\hline
\end{tabular}


Flood Insurance Program (NFIP) flood maps, the models have been documented in appendix 1 in a manner similar to FEMA's TSDN format (FEMA, 2011). The hydraulic models developed for this study were not submitted to FEMA under the Map Information Product (MIP) system at this time because updates to flood-insurance maps were not directly part of the study.

\section{Flood-Flow Updates}

The flood flows input to the HEC-RAS hydraulic models used in this study were updated from information from the "Magnitude of floods for selected annual-exceedance probabilities in Rhode Island, through 2010" by Zarriello and others (2012). The flood frequency report was developed as part of the same FEMA supported work as this study, in response to the 2010 flood. The report updates estimates of flood magnitudes at streamgages and provides regional equations for computing flood magnitudes at ungaged sites for 20-, 10-, 4-, 2-, 1-, 0.5-, and 0.2-percent AEP flows. Methods also were presented to calculate AEP flows at an ungaged site on a gaged stream, which were used to estimate flows at ungaged sites on the Pawcatuck and Wood Rivers.

The flood flows used in the latest countywide FIS for Washington County (FEMA, 2009) are the same as the flows used in the last community FIS, which were determined from methods and information that date back at least to the early 1980s. The 10, 2-, 1-, and 0.2-percent AEP flood flows in the effective FIS report and those computed in this study are summarized in table 3.

Table 3. Comparison of effective flood insurance study and updated flood flows in the Pawcatuck and Wood Rivers, Rhode Island.

[Available separately at http://pubs.usgs.gov/sir/2013/5193/ Tables/sir2013-5193_Tables3and4.xlsx]

In the Pawcatuck River, the AEP flows were determined at streamgages at Westerly, R.I. (01118500), and at Wood River Junction, R.I. (01117500), by Zarriello and others (2012). At ungaged sites, flows were determined from the ratio of the ungaged and gaged site drainage areas raised to an exponent ranging from 0.76 (for the 0.2-percent AEP flow) to 0.80 (for the 10-percent AEP flow), and multiplied by the AEP flow at the streamgage. Ungaged sites upstream of the Wood River confluence were indexed to the Pawcatuck River at Wood River Junction (01117500) streamgage; ungaged sites downstream of the Wood River confluence were indexed to the Pawcatuck River at Westerly (01118500) streamgage. At the 0.2-percent AEP, the updated flows averaged 46 percent greater (ranged from 33 to 64 percent greater) than those reported in the effective FIS. The updated flows averaged 39,34 , and 23 percent greater than the effective FIS flows at the 1-, 2-, and 10-percent AEP, respectively. Increases in the magnitude of flow for a given AEP, particularly at the lower exceedance probabilities, result from the additional record used in the analysis that included the two highest peaks of record (1982 and 2010) and the generally increasing trend in the magnitude of annual peak flows.

In the Wood River, the AEP flows were determined at the Hope Valley (01118000) streamgage by Zarriello and others (2012). The streamgage at Arcadia (01117800) was not used because of its distance upstream from the modeled reach. Flows at ungaged sites above and below the Hope Valley (01118000) streamgage were determined by a drainage-area weighting method that combined the AEP flow determined from the regional-flood equations with the AEP flow at the streamgage. At the 0.2-percent AEP, the updated flows averaged 51 percent greater (ranged from 43 to 56 percent greater) than the effective FIS flows. The updated flows averaged 44, 38 , and 24 percent greater than the effective FIS flows at the 1-, 2-, and 10-percent AEP, respectively. Differences between the effective FIS and updated AEP flows generally increased in the downstream direction. Similar to the changes in AEP flows in the Pawcatuck River, the additional Wood River record included the two highest peaks of record (1982 and 2010) since the effective FIS analysis and the general increasing trend in the magnitude of annual peak flows.

\section{Comparison of 2010 Flood High-Water Marks With Simulated Water Levels}

One of the objectives of this study was to compare the observed 2010 flood HWM elevations to those simulated for similar AEP floods to assess the effective FIS and updated hydraulic models WSEs. The HWMs obtained at 39 sites along the Pawcatuck River and 11 sites along the Wood River (Zarriello and Bent, 2011; fig. 2) were used for this analysis.

The 2010 flood was estimated to have about a 0.2-percent AEP on the basis of flood-frequency analysis of the annualpeak flows, weighted with the regional flood-flow equations at streamgages on the Pawcatuck River at Westerly (01118500) and Wood River Junction (011175000), and on the Wood River at Hope Valley (01118000) and Arcadia (01117800) (table 17 in Zarriello and others, 2012). The observed 2010 peak flows on the Pawcatuck River at Westerly (01118500) and Wood River Junction (01117500) (10,800 and 3,490 cubic feet per second $\left(\mathrm{ft}^{3} / \mathrm{s}\right)$, respectively), were about 3 - and 8-percent larger than the updated 0.2-percent AEP flows at these streamgages (10,500 and 3,220 $\mathrm{ft}^{3} / \mathrm{s}$, respectively) and about 48 and 37 percent larger than the effective FIS 0.2-percent AEP flows (7,900 and 2,310 ft $3 / \mathrm{s}$, respectively). The observed 2010 peak flow on the Wood River at Hope Valley (01118000) $\left(5,470 \mathrm{ft}^{3} / \mathrm{s}\right)$, was about 20 percent larger than the updated 0.2 -percent AEP flow $\left(4,570 \mathrm{ft}^{3} / \mathrm{s}\right)$ and 84 percent larger than the effective FIS 0.2-percent AEP flow $\left(2,970 \mathrm{ft}^{3} / \mathrm{s}\right)$. Correspondingly, observed 2010 HWM elevations along the Pawcatuck and Wood Rivers were generally higher than FIS and updated model WSEs for a 0.2-percent AEP flood. 


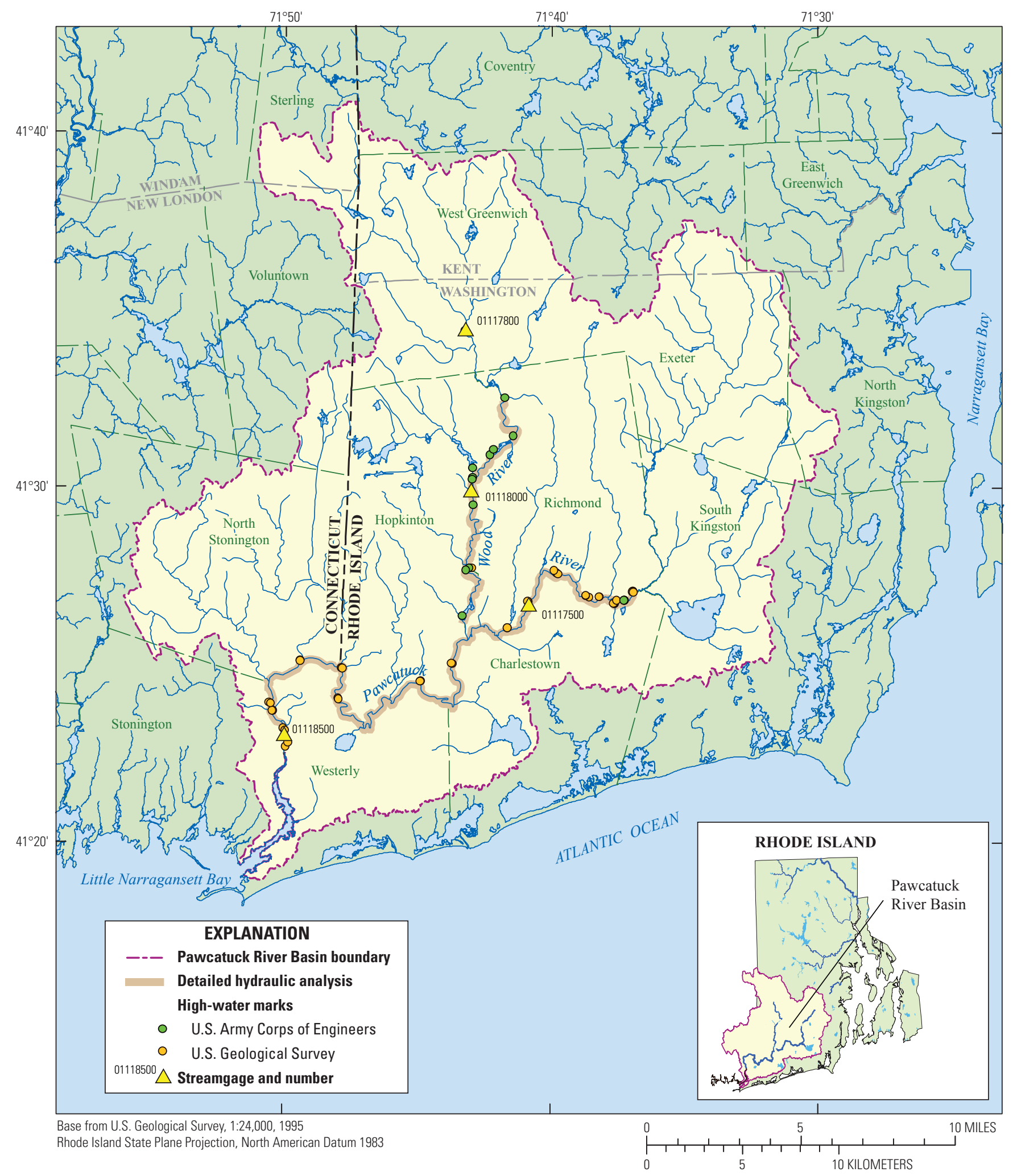

Figure 2. High-water marks obtained after the 2010 flood along reaches of detailed hydraulic analysis for the Pawcatuck and Wood Rivers, Rhode Island. 
Although the 0.2-percent AEP WSEs from the FIS and updated model are not a direct comparison to the 2010 flood peak flow and associated flood levels, the comparison still provides a basis for evaluating water levels for floods of the same AEP and the uncertainty of the flood WSEs. It should be noted that the 2010 peak flow outside of the streamgage locations also are unknown, which can result in uncertainty in a direct comparison of the 2010 HWMs and simulated WSEs. Also, note that the model simulated WSEs were determined on the basis of unobstructed flow from temporary debris, and the simulated water level is considered valid only if structures and the stream channel remain clear of debris. During field reconnaissance, field surveys, and from photos obtained from the Web, it was indicated that this condition does not always appear to be true, and a lower simulated WSE would be expected compared to the observed 2010 HWM elevations. It also should be noted that the quality of HWMs vary and are subject to uncertainty.

Two of the 2010 HWMs in the Pawcatuck River were downstream of the model limit. One HWM was upstream of the former Shannock Mill Pond Dam (at a distance of 130,786 ft in fig. 3), which was removed after the 2010 flood and before the hydraulic model field-survey work began. As such, the dam was not included in the updated model, but is in the effective FIS model. The effective FIS 0.2-percent AEP WSE at this site is about $1.1 \mathrm{ft}$ higher than the HWM elevation, but the updated model WSE is about $7.4 \mathrm{ft}$ lower than the HWM elevation reflecting the removal of the dam. This site and the two most downstream HWMs were not included in the following summary comparison.

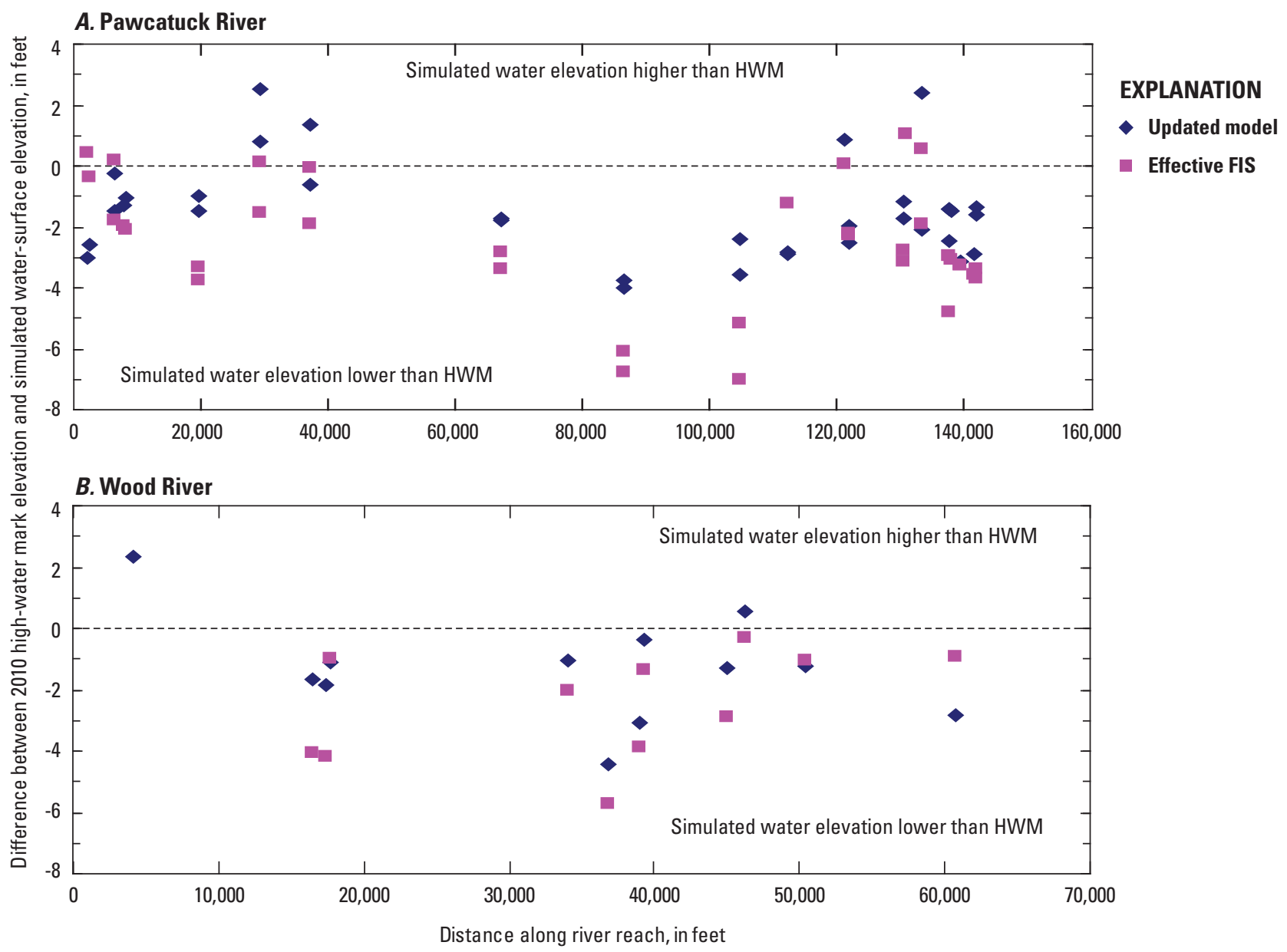

Figure 3. Differences between the 2010 flood high-water mark (HWM) elevations and simulated water-surface elevations from the effective flood insurance study (FIS) and the updated hydraulic model for the 0.2-percent annual exceedance probability flows for Rhode Island. A, Pawcatuck River. B, Wood River. 
The updated model simulated WSEs are in closer agreement with the observed 2010 HWMs than the WSE from the effective FIS at the 0.2-percent AEP flows (table 4), but the differences varied along the model reach (fig. 3). Boxplots (fig. 4) indicate that the 0.2-percent AEP simulated WSEs are almost always lower than the 2010 HWM elevations, and the differences between the FIS WSEs and the HWMs are more appreciable than those for the updated model. The HWM elevations on the Pawcatuck River, on average, were about $1.6 \mathrm{ft}$ higher than the WSEs simulated in the updated model and $2.5 \mathrm{ft}$ higher than the WSEs in the FIS. The HWM elevations on the Wood River, on average, were about $1.3 \mathrm{ft}$ higher than the WSEs simulated in the updated model and $2.5 \mathrm{ft}$ higher than the WSEs in the FIS. The range of differences between the HWMs and the FIS WSEs also was larger than that for the updated WSEs.

Table 4. Comparison of the effective flood insurance study (FIS) and updated hydraulic model water-surface elevations for the 0.2-percent annual exceedance probability flows to the 2010 flood high-water mark (HWM) elevations along the Pawcatuck and Wood Rivers, Rhode Island.

[Available separately at http://pubs.usgs.gov/sir/2013/5193/ Tables/sir2013-5193_Tables3and4.xlsx]

As previously noted, the 2010 peak flow was generally larger than the 0.2-percent AEP flow, which resulted in the FIS and updated model WSEs being lower than the 2010 HWMs. This is particularly evident in figure $3 \mathrm{~A}$, near the confluence of the Wood River (at about 92,700 ft), where the WSEs are well below the HWM elevations. This likely reflects the flow contribution from the Wood River, which for the model AEP flows are determined independently in the Pawcatuck and Wood Rivers. However, the combined 2010 peak flow $\left(8,960 \mathrm{ft}^{3} / \mathrm{s}\right)$ - from the Pawcatuck River at Wood River Junction (01117500) 3,490 ft $3 / \mathrm{s}$, and Wood River at Hope Valley (01118000) 5,470 ft3/s-is about 12 percent larger than the updated 0.2-percent AEP flow specified below the confluence $\left(8,020 \mathrm{ft}^{3} / \mathrm{s}\right)$ and about 83 percent larger than the FIS 0.2-percent AEP flow at this location $\left(4,900 \mathrm{ft}^{3} / \mathrm{s}\right)$. Upstream of the confluence, the additional flow from the Wood River likely caused greater backwater than simulated as evidenced by the difference between the simulated WSEs and the HWMs.

Differences caused by changes in the simulated flows used in the FIS and the updated model are sometimes masked by changes in the river conveyance. For example, although the flow in the upper part of the Wood River model is about 50 percent larger than the flow in the FIS model, the updated WSE upstream of Skunk Hill Road (at 50,386 ft) is about a foot lower than the WSE in the FIS. This reflects the improved conveyance under the Skunk Hill Road bridge, which was rebuilt in 1984, and was incorporated into the updated model analysis. The FIS analysis is based on the geometry of the old bridge.

In general, the differences between the effective FIS and updated model WSEs are not large given the differences in the flow specified in the updated model. For example, in
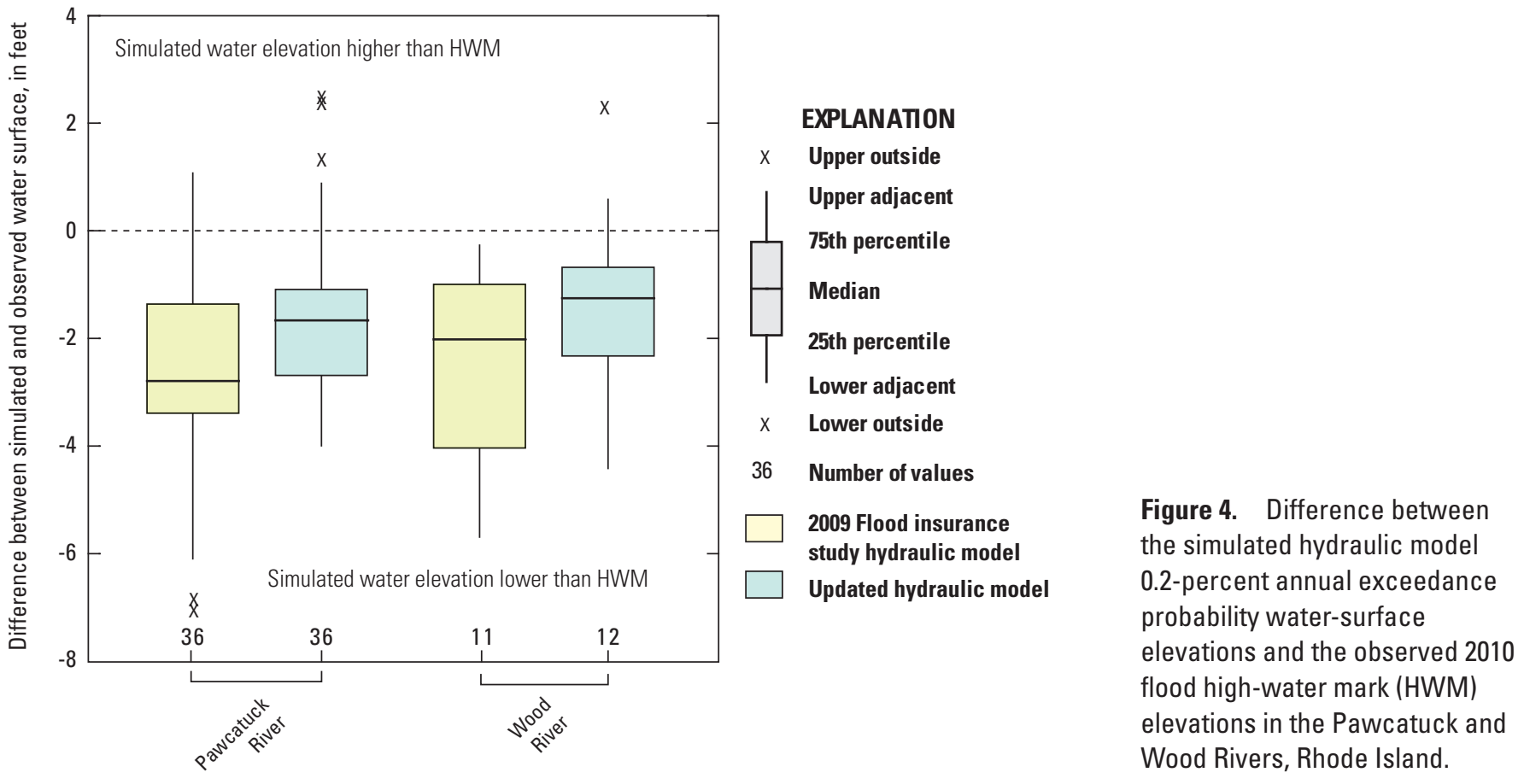
the Wood River, the updated model flows averaged about 51 percent more than the flows specified in the FIS, but the average difference between the FIS and updated model WSEs was only $0.83 \mathrm{ft}$. This indicates that the conveyance capacity of the river is sufficiently large that a change in flow of this magnitude doesn't result in large differences in water levels.

\section{Example Map of 2010 Flood Inundation}

The updated hydraulic model was used to construct an example map of the 2010 flood inundated areas and the depth of flooding on the basis of the 0.2-percent AEP flow, which as previously noted is the estimated AEP of the 2010 flood in the Pawcatuck River Basin. The example inundation map (fig. 5) for the Pawcatuck River is shown near the streamgage in Westerly where the photograph in figure 6 was taken. The depth of flooding indicated by the debris line on a fence about $4 \mathrm{ft}$ above land surface corresponds to the simulated WSE determined from the flood inundation map where the photograph was taken.

The flood inundation map depth is determined by the HEC-RAS simulated water elevations at each cross section and interpolated between cross sections to develop a gridded water-elevation map from which the LiDAR land-surface grid is subtracted. The resulting grid indicates the depth of flooding for each pixel nominally spaced every 2 meters $(6.24 \mathrm{ft})$ within the inundated area. Inundation maps are designed to work interactively with a geographic information system (GIS), which can focus to an area of interest to examine flooding at specific locations.

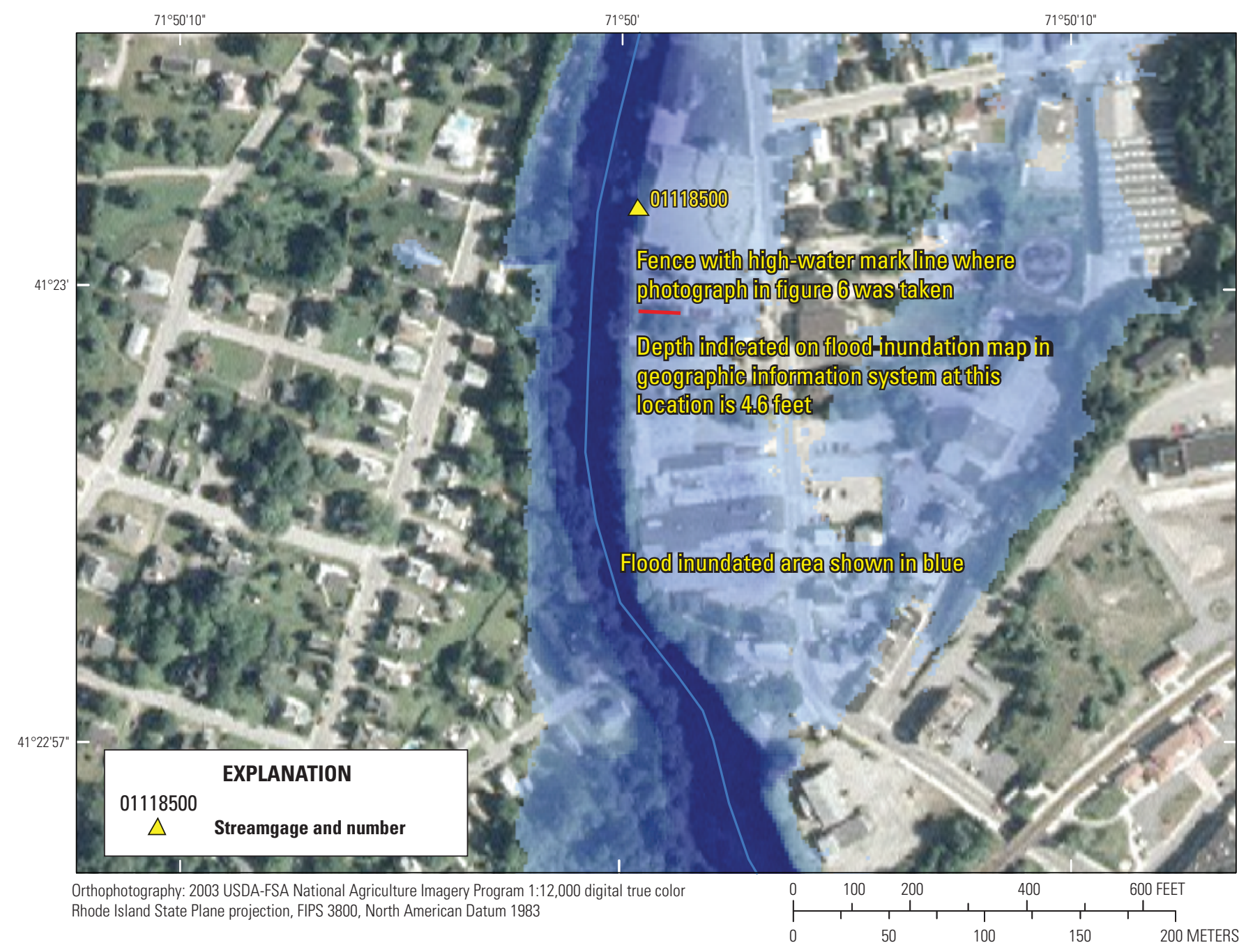

Figure 5. Flood inundation and depth of flooding at the 0.2-percent annual exceedance probability along the Pawcatuck River near the streamgage in Westerly, Rhode Island. 


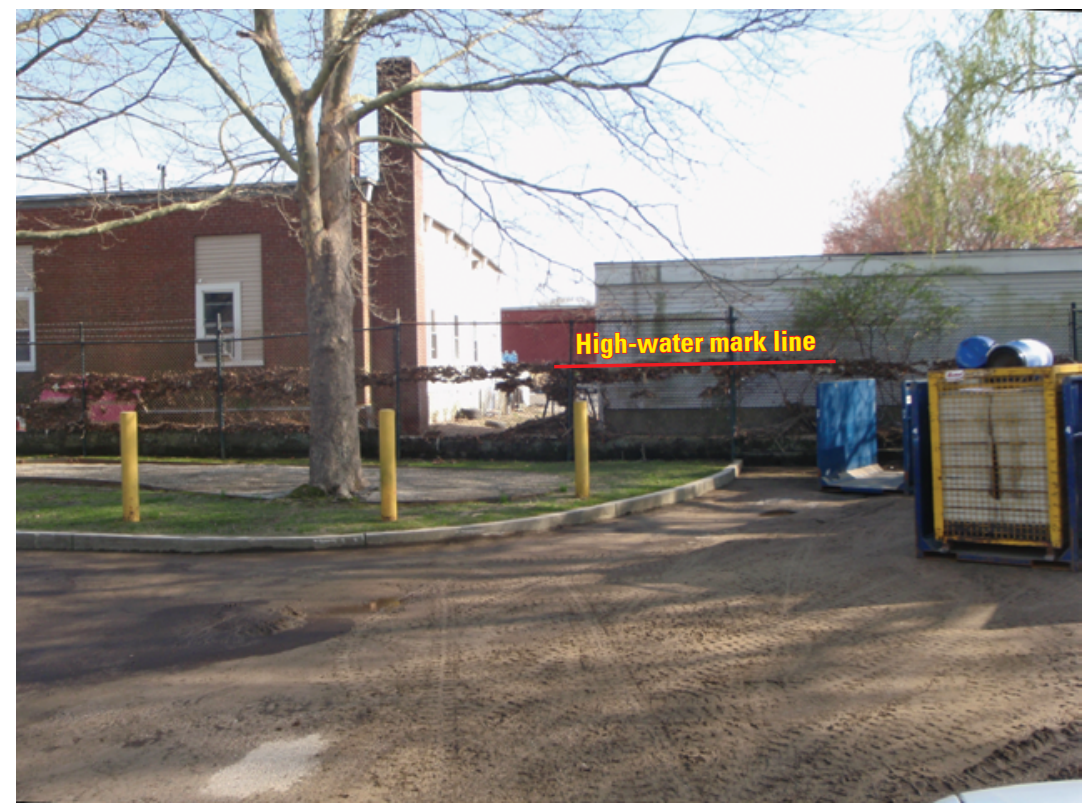

Figure 6. The high-water line on the fence following the March-April 2010 flood near the streamgage on the Pawcatuck River at Westerly (01118500), Rhode Island.

The hydraulic models developed during this study could be used to develop maps of incremental flood inundation over a range of flows and corresponding stream stages in the reaches near the streamgages. Incremental flood inundation maps provide information on area inundated at various flood magnitudes and could be incorporated into a Webbased map interface such as the USGS Flood Inundation Mapping Science Web site (http://water.usgs.gov/osw/flood_ inundation/) designed to help communicate where flooding occurs. Whether a flood map is indexed to a USGS streamgage or just to a flood magnitude, the information can be used to assess flood risk and help plan for future flood events. For the purposes of this investigation, only the magnitude of the 2010 flood was examined.

In this type of map, inundated areas as shown on figure 5 are for planning purposes only and are not intended for regulatory, permitting, or other legal purposes. The USGS provides these maps "as-is" for a quick reference, emergency planning tool but assumes no liability or responsibility from the use of this information. The actual inundated area and depth of water during the 2010 flood may differ from that shown because of debris, hydraulic model error, or elevation data inadequacies.

\section{Summary and Conclusions}

On March 30, 2010, an Emergency Declaration was declared for Rhode Island (Rhode Island Severe Storms and Flooding (EM-3311), http://www.fema.gov/disasters/3311), following heavy, persistent rains from late February through March 2010. The rainfall caused severe flooding and set, or nearly set, record high streamflows and water levels at many long-term streamgages in the State. In August 2010, the U.S. Geological Survey (USGS) entered into an agreement with the U.S. Department of Homeland Security-Federal Emergency Management Agency (FEMA) to document and characterize the March-April 2010 flood. As part of that agreement, this study was conducted to update hydraulic models in the Pawcatuck and Wood Rivers. The hydraulic models were used to simulate water-surface elevations (WSEs) from specified flows, boundary conditions, and the reach capacity or conveyance. The updated models, along with previously developed models for flood insurance studies (FIS), were evaluated in relation to high-water marks (HWMs) obtained following the March-April 2010 flood in a related USGSFEMA study. Hydraulic models are an important tool for flood-plain management, transportation infrastructure design, FIS, and other purposes to help minimize future flood damages and risks.

The Pawcatuck River Basin covers an area of about 295 square miles in southwestern Rhode Island and southeastern Connecticut that discharges into Little Narragansett Bay just south of the City of Westerly, R.I. The existing FIS hydraulic models were updated for about 39 miles (mi) of river reach including the Pawcatuck River (26.9 mi) and the Wood River (11.6 mi). The hydraulic models were updated to HEC-RAS, version 4.1.0 using steady-state simulations for flood flows with a 10-, 2-, 1-, and 0.2-percent annual exceedance probability (AEP). Flows were determined from streamgages on the Pawcatuck and Wood Rivers weighted with regional-flood equations from the results and methods reported by Zarriello and others (2012). The model updates 
included riverine structure surveys and associated approaches and exits to and from the structures to better reflect the current river conveyance conditions and to accurately georeference the structures. Additional cross-section information was obtained from recently acquired light detection and ranging (LiDAR) that provides accurate land-surface elevation data.

The flood flows reported in the 2009 effective FIS for Washington County are the same as the flood flows used in the last community FIS, which determined AEP flows from streamgage records from no later than the early 1980s. In general, the updated AEP flood flows used in this study were substantially larger than the AEP flows used in the effective FIS as a result of including the two highest peaks of record (1982 and 2010), and the general increasing trend in the annual peaks-flow magnitude. The updated 0.2-percent AEP flows averaged about 46 percent larger than the effective FIS flows in the Pawcatuck River and about 51 percent larger than the effective FIS AEP flows in the Wood River.

The HWMs from the 2010 flood were obtained at 39 sites along the model reach in the Pawcatuck River and 11 sites along the model reach in the Wood River. The 2010 observed peak flows in the Pawcatuck and Wood Rivers are estimated to have about a 0.2-percent AEP as determined from the updated flood-frequency analysis at streamgages on these rivers. The observed 2010 peak flow in the Pawcatuck River at Westerly (01118500) and Wood River Junction (01117500) streamgages was about 3 and 8 percent larger than the updated 0.2-percent AEP flow and about 48 and 37 percent larger than the effective FIS AEP flows. The observed 2010 peak flow at Wood River at Hope Valley (01118000) is about 20 percent larger than the updated 0.2-percent AEP flow and 84 percent larger than the effective FIS 0.2-percent AEP flow.

Differences between the 2010 HWMs and the simulated water-surface elevations (WSEs) at the 0.2-percent AEP flow in the effective FIS and the updated hydraulics model varied along the reach length, but in general, the updated model WSEs are in closer agreement with the 2010 HWMs than the effective FIS WSEs. The HWM elevations in the Pawcatuck River, on average, were about 1.6 feet ( $\mathrm{ft}$ ) higher than the WSEs simulated in the updated model and $2.5 \mathrm{ft}$ higher than the WSEs in the FIS. The HWM elevations in the Wood River, on average, were about $1.3 \mathrm{ft}$ higher than the WSEs simulated in the updated model and $2.5 \mathrm{ft}$ higher than the WSEs in the FIS.

Although the 0.2-percent AEP WSEs from the FIS and updated model are not a direct comparison to the 2010 flood peak flow and associated flood levels, the comparison provided a basis for evaluating water levels for floods of the same AEP and the uncertainty of the flood WSEs. The updated hydraulic models developed in this study appear to better represent the flood WSEs than the effective FIS models, as measured by the differences between the 2010 HWM elevations. The updated models also better represent current conditions and are consistent with high resolution land-surface elevation data. This study provides an assessment of the model for consideration in delineations of flood zones, flood-plain management operations, infrastructure design, and other purposes. It should be noted that the range of flows at the 95-percent confidence interval for a given AEP can produce appreciably different results than those simulated.

\section{References Cited}

Brunner, G.W., 2010a, HEC-RAS river analysis systemUser's manual (ver. 4.1): Davis, Calif., U.S. Army Corps of Engineers, Hydrologic Engineering Center, CPD-68, 766 p.

Brunner, G.W., 2010b, HEC-RAS river analysis systemHydraulic reference manual (ver. 4.1): Davis, Calif., U.S. Army Corps of Engineers, Hydrologic Engineering Center, CPD-69, 411 p.

FEMA - Federal Emergency Management Agency

FEMA, 2009, Flood Insurance Study—Washington County, Rhode Island: Community no. 44009CV000A, Preliminary June 1, 2009, 143 p.

FEMA, 2011, Guidelines and standards for flood hazard mapping partners, Appendix M-Data capture standards: $170 \mathrm{p}$.

Heidemann, H.K., 2012, LiDAR base specification, version 1.0: U.S. Geological Survey Techniques and Methods, book 11, chap. B4, 63 p. (available at http://pubs.usgs.gov/ $\mathrm{tm} / 11 \mathrm{~b} 4 /$.)

Shearman, J.O., 1976, Computer applications for stepbackwater and floodway analyses: U.S. Geological Survey Open-File Report 76-499, 103 p.

U.S. Army Corps of Engineers, 1991, HEC-2 water surface profiles user's manual: Davis, Calif., U.S. Army Corps of Engineers, Hydrologic Engineering Center, 334 p.

Zarriello, P.J., Ahearn, E.A., and Levin, S.B., 2012, Magnitude of flood flows for selected annual exceedance probabilities in Rhode Island through 2010 (ver. 1.1, revised October 17, 2012): U.S. Geological Survey Scientific Investigations Report 2012-5109, 93 p. (available at http://pubs.usgs.gov/ $\operatorname{sir} / 2012 / 5109 /$.)

Zarriello, P.J., and Bent, G.C., 2011, Elevation of the MarchApril 2010 flood high water in selected river reaches in Rhode Island: U.S. Geological Survey Open-File Report 2011-1029, 34 p. (available at http://pubs.usgs.gov/ ofr/2011/1029/.) 
THIS PAGE INTENTIONALLY LEFT BLANK 


\title{
Appendix 1. Pawcatuck River and Wood River Hydraulic Models: Technical Support Data Notebook
}

\author{
The hydraulic models developed in this study may be used to update Digital Flood Insurance \\ Rate Map (DFIRM) by the U.S. Department fo Homeland Security-Federal Emergency Manage- \\ ment Agency (FEMA), but have not been approved for that purpose. As such, modifications to \\ the models described in this report may be made prior to DFIRM production.
}




\section{Background}

Following severe flooding during March-April 2010, the U.S. Geological Survey (USGS) and the U.S. Department of Homeland Security-Federal Emergency Management Agency (FEMA) entered into an agreement to characterize the hydrology and hydraulics of the event in selected parts of Rhode Island. In this study, existing hydraulic models of the Pawcatuck and Wood Rivers (fig. 1) were updated to Hydrologic Engineering Center-River Analysis System (HEC-RAS), version 4.1.0. Updates to the models included field surveys made at structures along the modeled reaches, incorporation of high resolution land-surface elevation data acquired in November 2011, conversion of existing hydraulic model information where needed, and updated flood flows at gaged and ungaged sites from a recent related study.

Reaches selected for detailed hydraulic analysis were determined jointly by FEMA and the Rhode Island Emergency Management Agency, which included the Pawcatuck and Wood Rivers. The effective FEMA flood insurance study (FIS) for these rivers is covered in the Washington County FIS (FEMA, 2009). The countywide FIS update was largely compiled from earlier community FIS reports, which are summarized in table 1-1.

The updated hydraulic models were developed by the USGS for FEMA under Interagency Agreement number HSFEHQ-10-X-0672. The agreement began on August 11, 2010, and ended on March 30, 2013.

\section{Scope of Work}

Details about the hydraulic models for the Pawcatuck and Wood Rivers in Washington County, Rhode Island, are included in this appendix. The appendix follows the general format of the Technical Support Data Notebook (TSDN) guidelines by FEMA (2011) for model documentation.

\section{Pawcatuck River}

The model portion of the Pawcatuck River begins near its mouth at Little Narragansett Bay, a tidal embayment of the Atlantic Ocean just south of the City of Westerly, R.I., and ends 26.9 mi upstream at the South Kingston town line (fig. 1). The river flows west-southwest through the Rhode Island towns of Richmond, Charleston, Hopkinton, and Westerly, and the Connecticut towns of North Stonington and Stonington.

\section{Wood River}

The modeled reach of the Wood River starts about $0.7 \mathrm{mi}$ upstream of the confluence with the Pawcatuck River and ends about 11.6 mi north near Arcadia, R.I., just above Barberville Dam. The reach flows through the Rhode Island towns of Richmond and Hopkinton.

\section{Engineering Analyses}

The engineering analyses include hydrologic and hydraulic analyses. The hydrologic analysis provides the magnitude of flood flows specified in the hydraulic models. The hydraulic analysis is the development of the hydraulic model used to simulate the water-surface elevation (WSE) for a specified flood flow.

Table 1-1. Summary of updated hydraulic model reaches in the Pawcatuck and Wood Rivers, communities along the reach, and flood insurance study (FIS) for the reach.

[Effective FIS date is the countywide FIS report, which supersedes all previous community FIS reports]

\begin{tabular}{lllc}
\hline \multicolumn{1}{c}{ Reach name } & \multicolumn{1}{c}{ Effective FIS date } & Community & Community number \\
\hline See below & Effective (2013) FIS \\
\hline Pawch 2009 & Washington County, all jurisdictions & 44009 \\
& \multicolumn{3}{c}{ Supersedes community studies } \\
& 1980 & Charlestown & 445395 \\
& 1980 & Hopkinton & 440028 \\
& 1972,1986 & Richmond & 440031 \\
& & Westerly & 445410 \\
Wood River & 1980 & & 440028 \\
& 1980 & Hopkinton & 440031 \\
\hline
\end{tabular}




\section{Hydrologic Analyses}

The hydrologic analyses used in this study were from updated annual exceedance probability (AEP) flows at streamgages and the regional-flood equations for ungaged streams developed in a related USGS-FEMA study by Zarriello and others (2012). Flows at streamgages for 10-, 2-, $1-$, and 0.2 percent AEP floods were determined by the standard log-Pearson type-III method described in Bulletin 17B of the Hydrology Subcommittee (U.S. Interagency Advisory Committee on Water Data, 1982) and a modification of this method known as the expected moments algorithm (EMA). The report by Zarriello and others (2012) provides equations for adjusting flood flows at an ungaged site on a gaged stream that was used for estimating flows in the Pawcatuck and Wood Rivers.

Flows specified in HEC-RAS are specified in the model from upstream to downstream until a new flow is specified. Specified flows were typically determined at transition points where the drainage area changes appreciably, such as at the confluence of a large tributary. For example, the flow in the reach above the tributary would be determined from the drainage area just above the confluence and used as the flow in the reach above the tributary until the next large tributary. The process would repeat until representative flows are determined for the model reach. The drainage area reported in the tables that follow were generally determined at the downstream end of the reach where the flow applies, as previously described; however, the cross section (and description) specified in each of the reach tables is at an upstream end of where the flow is first specified.

\section{Pawcatuck River}

Flows specified for the Pawcatuck River were determined from the streamgage at Westerly, R.I. (01118500), annual peak-flow records for 1941-2010 and historical information from the 1927 and 1936 floods, and from the streamgage at Wood River Junction, R.I. (01117500), annual peak-flow records from 1941 to 2010. At ungaged sites (table 1-2), flows were determined from the ratio of the ungaged and gaged site drainage areas raised to an exponent ranging from 0.76 (for the 0.2-percent AEP flow) to 0.80 (for the 10-percent AEP flow) and multiplied by the AEP flow at the streamgage. Ungaged sites upstream of the Wood River confluence were indexed to the Pawcatuck River at Wood River Junction (01117500) streamgage; ungaged sites downstream of the Wood River confluence were indexed to the Pawcatuck River at Westerly (01118500) streamgage.

\section{Wood River}

The AEP flows specified for the Wood River were determined from streamgage records at Hope Valley, R.I. (01118000), for 1942-2010 and historical information from the 1936 flood. Flows at ungaged sites (table 1-3) on the modeled reach above and below the Hope Valley streamgage (01118000) were determined by a drainage area weighted estimate of the AEP flow determined from the regional-flood equations and the AEP flow at the streamgage.

Table 1-2. Annual exceedance probability flows specified in the hydraulic model for the Pawcatuck River, Rhode Island.

[ft 3 s, cubic foot per second; $\mathrm{mi}^{2}$, square mile; USGS, U.S. Geological Survey]

\begin{tabular}{|c|c|c|c|c|c|c|c|}
\hline \multirow{2}{*}{ Description } & \multicolumn{2}{|c|}{ Cross section station } & \multirow{2}{*}{$\begin{array}{l}\text { Drainage area }{ }^{1} \\
\qquad\left(\mathrm{mi}^{2}\right)\end{array}$} & \multicolumn{4}{|c|}{$\begin{array}{c}\text { Discharge }\left(\mathrm{ft}^{3} / \mathrm{s}\right) \text { for specified percent } \\
\text { annual exceedance probability }\end{array}$} \\
\hline & From & To & & 10 & 2 & 1 & 0.2 \\
\hline Upstream of Taney Brook confluence & 134,800 & 126,116 & 92.7 & 1,210 & 1,860 & 2,190 & 3,060 \\
\hline Upstream of White Brook confluence & 125,822 & 118,721 & 95.9 & 1,240 & 1,910 & 2,250 & 3,140 \\
\hline Upstream of Wood River confluence & 104,777 & 93,351 & 114 & 1,430 & 2,180 & 2,570 & 3,580 \\
\hline Upstream of Poquiant Brook confluence & 92,668 & 79,036 & 206 & 3,080 & 4,790 & 5,680 & 8,020 \\
\hline Upstream of Tomaquag Brook confluence & 76,569 & 61,422 & 218 & 3,220 & 5,010 & 5,940 & 8,370 \\
\hline Upstream of Ashaway River confluence & 57,744 & 28,159 & 242 & 3,500 & 5,430 & 6,440 & 9,060 \\
\hline
\end{tabular}

${ }^{1}$ The drainage area is the downstream point ("To" station) where the flow was determined; the "From" station and "Description" is the upstream point where the flow is first specified. 
Table 1-3. Annual exceedance probability flows specified in the hydraulic model for the Wood River, Rhode Island.

$\left[\mathrm{ft}^{3} / \mathrm{s}\right.$, cubic foot per second; $\mathrm{mi}^{2}$, square mile; --, not applicable; USGS, U.S. Geological Survey]

\begin{tabular}{|c|c|c|c|c|c|c|c|}
\hline \multirow[t]{2}{*}{ Description } & \multicolumn{2}{|c|}{ Cross section station } & \multirow{2}{*}{$\begin{array}{l}\text { Drainage area }{ }^{1} \\
\qquad\left(\mathrm{mi}^{2}\right)\end{array}$} & \multicolumn{4}{|c|}{$\begin{array}{c}\text { Discharge }\left(\mathrm{ft}^{3} / \mathrm{s}\right) \text { for specified percent } \\
\text { annual exceedance probability }\end{array}$} \\
\hline & From & To & & 10 & 2 & 1 & 0.2 \\
\hline Secondary channel below Barberville Dam & 60,800 & 60,300 & -- & 380 & 450 & 480 & 700 \\
\hline Main channel below Barberville Dam & 60,798 & 60,699 & -- & 900 & 1,060 & 2,000 & 2,800 \\
\hline USGS streamgage 01118000 & 39,247 & 36,837 & 72.4 & 1,650 & 2,650 & 3,180 & 4,570 \\
\hline Upstream of Canonchet Brook & 35,877 & 20,740 & 76.8 & 1,730 & 2,780 & 3,330 & 4,760 \\
\hline Downstream of Canonchet Brook & 19,065 & 17,760 & 86.2 & 1,950 & 3,130 & 3,740 & 5,290 \\
\hline Secondary channel below Woodville Dam & 17,650 & 16,900 & -- & 750 & 730 & 840 & 990 \\
\hline
\end{tabular}

${ }^{1}$ The drainage area is the downstream point ("To" station) where the flow was determined; the "From" station and "Description" is the upstream point where the flow is first specified.

\section{Hydraulic Analyses}

Hydraulic analyses of selected reaches were made using HEC-RAS, version 4.1.0 (Brunner, 2010a, b). The initial scope of the study was to update the existing FIS hydraulic models to HEC-RAS, but as previously noted, it became apparent that the model conveyance was not always representative of current conditions. In addition, a simple conversion of the FIS hydraulic model could cause improper georeferencing of riverine structures. Field-survey data collected during this study, together with the use of recently available light detection and ranging (LiDAR) data, improved the representativeness of the river hydraulic models and the simulated floodwater levels. Field survey and LiDAR data were incorporated into the updated analyses using the geographic support tool HEC-GeoRAS (Ackerman, 2011), which allows the exchange of georeferenced information with HEC-RAS.

After the initial hydraulic simulations were made, the error and warning messages generated by HEC-RAS and FEMA's CHECK-RAS application were reviewed. The results were assessed for validity, accuracy, and appropriate engineering practices. Some of the areas of concern included the critical water surface calculations, WSE differences between adjacent cross sections, and correct usage of ineffective flow areas. After revisions were made, the results of revised simulations were reviewed, and the process was repeated until errors were resolved and the remaining warnings were judged acceptable.

\section{Solution Check at Bridges and Culverts}

During high-flow conditions, pressure flow may occur at bridges and culverts when the water surface on the upstream side of the structure equals or exceeds the low chord of the bridge or the top of the culvert. The possibility of this type of condition was checked at all bridges and culverts where the WSE derived from the energy equation was found to be near the low chord of a bridge or the top of the culvert. Although the energy-equation method is applicable to the widest range of hydraulic problems (Brunner, 2010b), pressure-flow computations are needed when the water surface comes into contact with the low bridge chord or top of the culvert. In a number of cases, pressurized flow is controlled by the downstream WSE, and a coefficient for the applicable flow equation is specified.

During high-flow conditions, road overflow may occur that results in weir flow if there is sufficient drop on the downstream side of the structure, and the structure is not submerged. Submergence is determined as a function of the ratio of the downstream flow depth to the upstream energy grade line, as measured from the minimum high chord of the deck. The HEC-RAS uses a default maximum submergence ratio of 0.95 for weir flow calculations. When the 0.95 ratio is exceeded, the HEC-RAS Applications Guide (Warner and others, 2010) states:

"When this ratio is exceeded for a bridge analysis, the program will switch from the weir-flow equation to the energy method to determine the upstream flow depth. For a culvert analysis, this ratio is 
not used because the program cannot perform a backwater analysis through a culvert flowing full. Therefore, a weir analysis will always be used when overflow occurs."

As a result, when road overflow occurs at a culvert and the weir-flow computation is determined to be invalid, HECRAS employs an energy-based solution. For this condition, the roadbed does not act like a weir and a weir flow coefficient for submergence is used.

\section{Pawcatuck River}

A HEC-RAS model was developed for a 26.9 mi reach of the Pawcatuck River starting near its mouth in Westerly R.I., to the South Kingston town line (fig. 1-1). The model was developed from cross-section and riverine-structure data surveyed in the field by the USGS, from the existing FIS hydraulic model, and from 2011 LiDAR data. Flows estimated for 10-, 2-, 1-, and 0.2-percent AEP floods were used with cross-sectional and riverine-structure information to compute the corresponding water-surface profiles.

\section{Model Limit and Baseline Stationing}

The Pawcatuck River flows generally west-southwest in southwest Rhode Island. The HEC-RAS model starts near its mouth at Little Narragansett Bay and ends at the South Kingston town line at the border with the towns of Richmond and Charlestown. Stationing for the model is in feet, referenced from the start of the model near the mouth of the river, about $0.3 \mathrm{mi}$ downstream of the streamgage at Westerly (01118500) and about $165 \mathrm{ft}$ downstream of the Amtrak railroad bridge.

\section{Cross-Section and Structural-Geometry Data}

The Pawcatuck River HEC-RAS model consists of 362 cross sections, 26 bridges, and 5 dams. The USGS surveyed riverine structures and approaches and exits downstream of Burdickville (12 bridges and 3 dams); upstream of Burdickville the riverine structure data were mostly obtained from the effective FIS model input. At the time of the field surveys, a small dam (Shannock Mill Pond Dam) just upstream of Old Shannock Road existed (at station 130,342), but recent aerial photos indicate the dam was removed. Therefore, the dam was removed leaving 5 dams in the main channel of the HEC-RAS model (table 1-5). Most non-structural cross sections were obtained from the effective FIS model input. Elevations from LiDAR were used to supplement or extend the cross sections as needed. All survey and model data are referenced to NAD 83 horizontal datum and NAVD 88 vertical datum.

No synthetic cross sections were generated for the model. However, sections at the upstream and downstream faces of structures were sometimes interpolated from the approach and exit cross sections, and the structure geometry. Ineffective flow areas were specified in channel cross sections as needed.
Table 1-4. Summary of cross sections in the hydraulic model for the Pawcatuck River, Rhode Island.

[Available separately at http://pubs.usgs.gov/sir/2013/5193/ Appendix/sir2013-5193_Appendix1.xls]

\section{Starting Water-Surface and Backwater Elevation}

The Pawcatuck River is affected by backwater conditions from Little Narragansett Bay. A WSE of $5.23 \mathrm{ft}$ NAVD 88 was used as the starting boundary condition for all AEP simulations, which corresponds to the 10-year high tide at Little Narragansett Bay. The 10-year high tide (4.93 ft) was determined by the generalized logistic (GLO) distribution fit reported for New London, Conn., in the tidal profiles for New England coastline (MOD, 2008) and updated from information in a STARR report to FEMA (Timothy Hillier, CDM Smith, STARR Coastal Processes Lead, written commun., 2010). The tide elevation at New London, Conn., was adjusted for difference in tide $(0.30 \mathrm{ft})$ between this location and near the mouth of the Pawcatuck River at Watch Hill Point from tide flood profiles reported by the U.S. Army Corps of Engineers (1988).

\section{Manning's Roughness Coefficients}

Manning's roughness coefficients (n) for the main channel and overbank areas of the Pawcatuck River were largely obtained from the existing FIS hydraulic model. Some adjustments to the " $n$ " values were made from field observations and aerial photographs and by comparing the observed 2010 flood HWMs to the HEC-RAS model results. Manning's roughness coefficients range in value from 0.028 to 0.040 for the main channel with a median of 0.034 , and from 0.045 to 0.10 for the overbank areas with a median of 0.07 .

\section{Flow Lengths}

Main-channel and overbank-flow lengths were computed through the use of HEC-GeoRAS (Ackerman, 2011). Flow paths were defined by the National Hydrography Dataset (NHD) stream centerline and by the modeler for the overbanks. The median main channel length between cross sections was $290 \mathrm{ft}$ and ranged from 28 to $4,131 \mathrm{ft}$. Short and long channel reaches typically are caused by river meanders.

\section{Hydraulic Structures}

Water levels in the Pawcatuck River can be affected by 26 bridges and 5 dams. Shannock Mill Pond Dam was removed prior to the field survey but was present at the time of the 2010 flood. The updated model does not include this dam. Table 1-5 lists the types of structures and the solution types used at bridges to compute the flood profile for the 1-percent AEP flow. Road overflow at the 1-percent AEP flow is noted. The solution type at bridges was determined by the model on the basis of the simulated conditions at the structure, which can vary according to the AEP flow. 

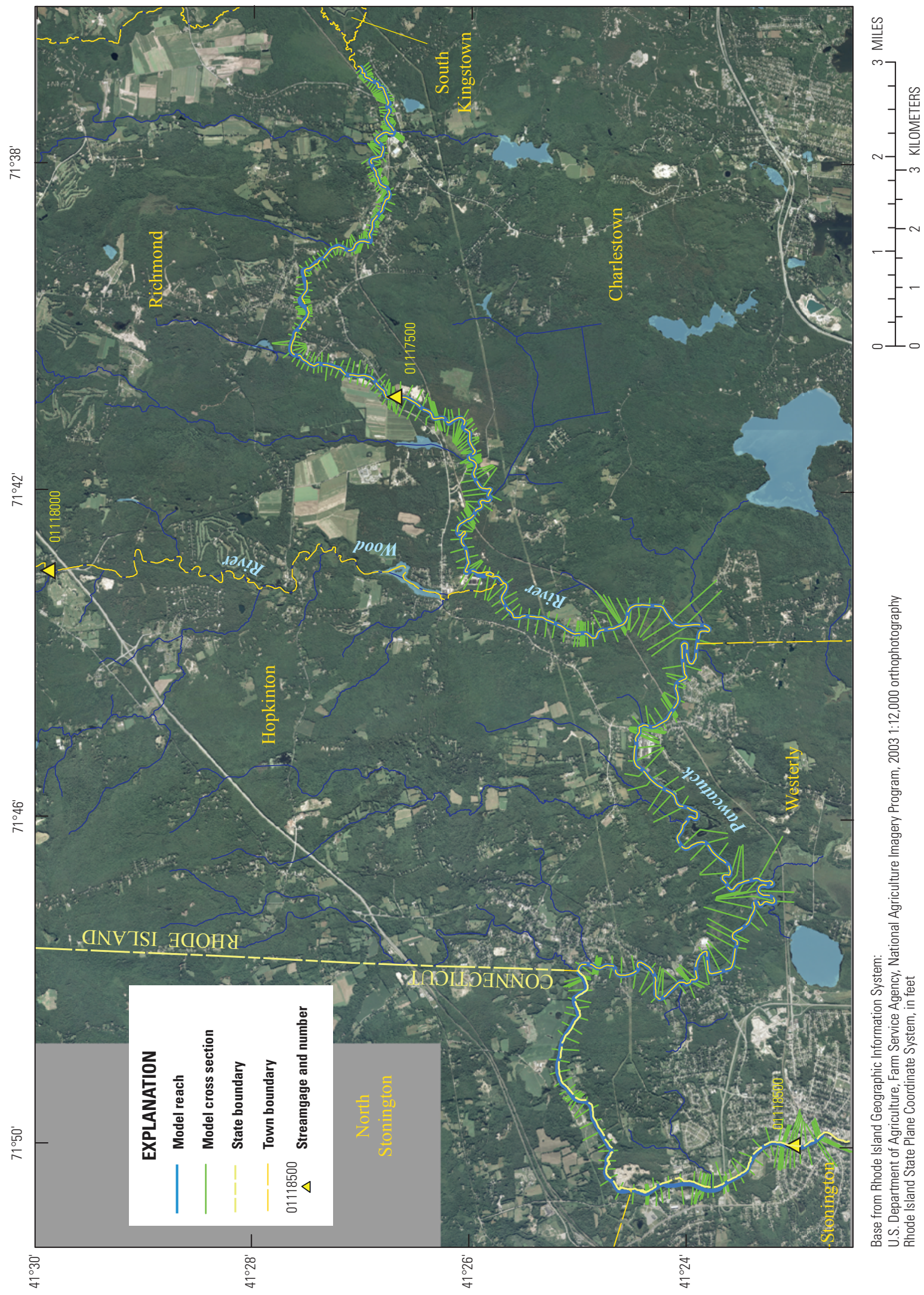

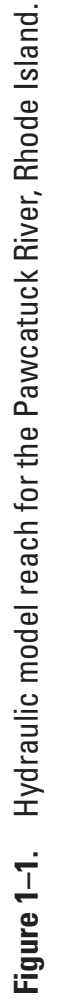


Table 1-5. Summary of structures in the hydraulic model for the Pawcatuck River, Rhode Island.

[River station rounded to the nearest foot; AEP, annual exceedance probability; Inl Struct, in line structure; --, not applicable]

\begin{tabular}{|c|c|c|c|c|}
\hline \multirow{2}{*}{$\begin{array}{l}\text { River station } \\
\text { (feet) }\end{array}$} & \multirow{2}{*}{ Description } & \multirow{2}{*}{ Structure type } & \multicolumn{2}{|c|}{ 1-percent AEP flow } \\
\hline & & & Road overflow & Solution type \\
\hline 337 & Amtrak 1 & Bridge & No & Energy \\
\hline 2,465 & Arch Street & Bridge & No & Energy \\
\hline 6,698 & Veterans Way (Route 78) & Bridge & No & Energy \\
\hline 8,092 & White Rock Road & Bridge & No & Energy \\
\hline 11,342 & Alice Court Dam & Inl Struct & -- & Weir \\
\hline 19,641 & Boom Bridge Road & Bridge & $\mathrm{No}^{1}$ & Energy \\
\hline 27,301 & Post Office Lane & Bridge & Yes & Energy \\
\hline 29,044 & Potter Hill Dam & Inl Struct & -- & Weir \\
\hline 29,178 & Potter Hill Road & Bridge & No & Energy \\
\hline 37,205 & Main Street-Ashaway Road (Route 3) & Bridge & No & Energy \\
\hline 66,785 & Bradford Dye & Inl Struct & -- & Weir \\
\hline 67,108 & Alton Bradford Road (Route 91) & Bridge & No & Energy \\
\hline 69,485 & Amtrak 2 & Bridge & No & Energy \\
\hline 83,900 & Amtrak 3 & Bridge & No & Energy \\
\hline 86,439 & Burdickville Road & Bridge & No & Energy \\
\hline 99,698 & Amtrak 4 & Bridge & No & Energy \\
\hline 104,555 & Kings Factor Road & Bridge & No & Energy \\
\hline 109,357 & Amtrak 5 & Bridge & No & Energy \\
\hline 112,384 & Alton Carolina Road (Route 91) & Bridge & $\mathrm{No}^{1}$ & Energy \\
\hline 121,660 & Carolina Main Street (Route 112) & Bridge & No & Energy \\
\hline 128,437 & Amtrak 6 & Bridge & No & Energy \\
\hline 130,342 & Old Shannock Road & Bridge & No & Energy \\
\hline 132,579 & Amtrak 7 & Bridge & No & Energy \\
\hline 133,154 & Shannock Road & Bridge & No & Energy \\
\hline 133,232 & Shannock Road Dam & Inl Struct & -- & Weir \\
\hline 136,798 & Amtrak 8 & Bridge & No & Energy \\
\hline 137,341 & Factory walkway & Bridge & No & Energy \\
\hline 137,455 & Sherman Avenue & Bridge & No & Energy \\
\hline 137,832 & Kenyon Iron Work & Inl Struct & -- & Weir \\
\hline 139,345 & South County Trail (Route 2) & Bridge & No & Energy \\
\hline 141,624 & Biscuit City Road & Bridge & No & Energy \\
\hline
\end{tabular}

${ }^{1}$ Road overflow at the 0.2 -percent AEP flow. 


\section{Wood River}

A HEC-RAS model was developed for an $11.6 \mathrm{mi}$ reach of the Wood River starting near its confluence with the Pawcatuck River just downstream of Alton Pond and ending just upstream of the Barberville Dam near Arcadia (fig. 1-2). The confluence with the Pawcatuck River is about 0.7 mi downstream of the Alton Pond outlet (Church Street). The model was developed from cross-section and riverinestructure data surveyed in the field by the USGS, the effective FIS models, and 2011 LiDAR data. Peak flow estimates for 10-, 2-, 1-, and 0.2-percent AEP floods were used with crosssectional and riverine-structure information to compute the corresponding water-surface profiles.

\section{Model Limit and Baseline Stationing}

The Wood River generally flows south in southwestern Rhode Island. The model starts $0.7 \mathrm{mi}$ upstream from its confluence with the Pawcatuck River, downstream of Alton Pond Dam and ends just upstream from Barberville Dam. The water level in the short reach below Alton Pond Dam is largely controlled by the water elevation in the Pawcatuck River; therefore, it is not included in the Wood River model. The reach is bordered to the west by the Town of Hopkinton and to the east by the Town of Richmond. Stationing is in feet, referenced from the confluence with the Pawcatuck River.

\section{Cross-Section and Structural-Geometry Data}

The Wood River model is divided into five main channel reaches and two secondary channel reaches. A short segment (about $500 \mathrm{ft}$ ) defines the reach above Barberville Dam (Upper) just upstream of Arcadia Road. At the dam, a small secondary channel was defined to account for an old mill raceway (Arcadia canal) and the main channel reach, referred to as "Arcadia over dam." After the channels merge, about $350 \mathrm{ft}$ downstream from the split, the reach is referred to as the "Main Reach," which runs for about 8 mi until it splits again just above the Woodville Dam. At Woodville Dam, a secondary channel (Woodville Canal) defines an old mill raceway similar to the Arcadia Canal that bypasses flow from the main channel (Woodville over dam) until they merge about $1,100 \mathrm{ft}$ downstream of the split. The merged channel (Lower) runs about $2.4 \mathrm{mi}$ to Alton Pond Dam.

The Wood River HEC-RAS model consists of 111 cross sections, 10 bridges, and 9 dams (table 1-6). Of these, the secondary split channels included 12 cross sections, 3 dams, and 2 bridges. The USGS surveyed bridges and dams and their approaches and exits; other cross sections were obtained from the effective FIS. Elevations from LiDAR data were used to supplement or extend the surveyed cross sections as needed. All survey and model data are referenced to NAD 83 horizontal datum and NAVD 88 vertical datum.

No synthetic cross sections were generated for the model. Upstream and downstream faces of structures are not included in table 1-6. Ineffective flow areas and obstructions were specified in channel cross sections as needed.

Table 1-6. Summary of cross sections in the hydraulic model for the Wood River, Rhode Island.

[Available separately at http://pubs.usgs.gov/sir/2013/5193/ Appendix/sir2013-5193_Appendix1.xls]

\section{Starting Water-Surface and Backwater Elevation}

The starting WSE at the downstream end of the Wood River model was determined from the normal depth computed from the channel slope $(0.0004 \mathrm{ft} / \mathrm{ft})$ downstream of Alton Pond Dam. Backwater from the Pawcatuck River does not affect water levels in the Wood River above the Alton Pond Dam.

\section{Manning's Roughness Coefficients}

Manning's roughness coefficients (n) for the main channel and overbank areas of the Wood River were largely obtained from the existing FIS hydraulic model. Some adjustments to the " $n$ " values were made from field observations and aerial photographs and by comparing the observed 2010 flood HWMs to the HEC-RAS model results for the 2010 flood discharge. Manning's roughness coefficients range in value from 0.035 to 0.065 for the main channel with a median of 0.034 , and from 0.04 to 0.160 for the overbank areas with a median of 0.10. Estimates of Manning's roughness coefficients in the secondary channels (old mill raceways) ranged from 0.02 to 0.035 for the main channel with a median of 0.03 .

\section{Flow Lengths}

Main-channel and overbank-flow lengths were computed through the use of HEC-GeoRAS (Ackerman, 2011). Flow paths were defined by the NHD stream centerline and by the modeler for the overbanks. The median main channel length between cross sections was $275 \mathrm{ft}$ and ranged from 8 to $3,848 \mathrm{ft}$ with similar distances for the left and right banks. Large differences in channel lengths along the banks are caused by meanders in the river.

\section{Hydraulic Structures}

Water levels in the Wood River can be affected by 10 bridges and 9 dams (table 1-7). Most structures were surveyed by the USGS in 2011. Table 1-7 lists the types of structures and the solution types used at bridges to compute the flood profile for the 1-percent AEP flow. Road overflow at the 1-percent AEP flow is noted. The solution type at bridges was determined by the model on the basis of the simulated conditions at the structure, which can vary according to the AEP flow. 


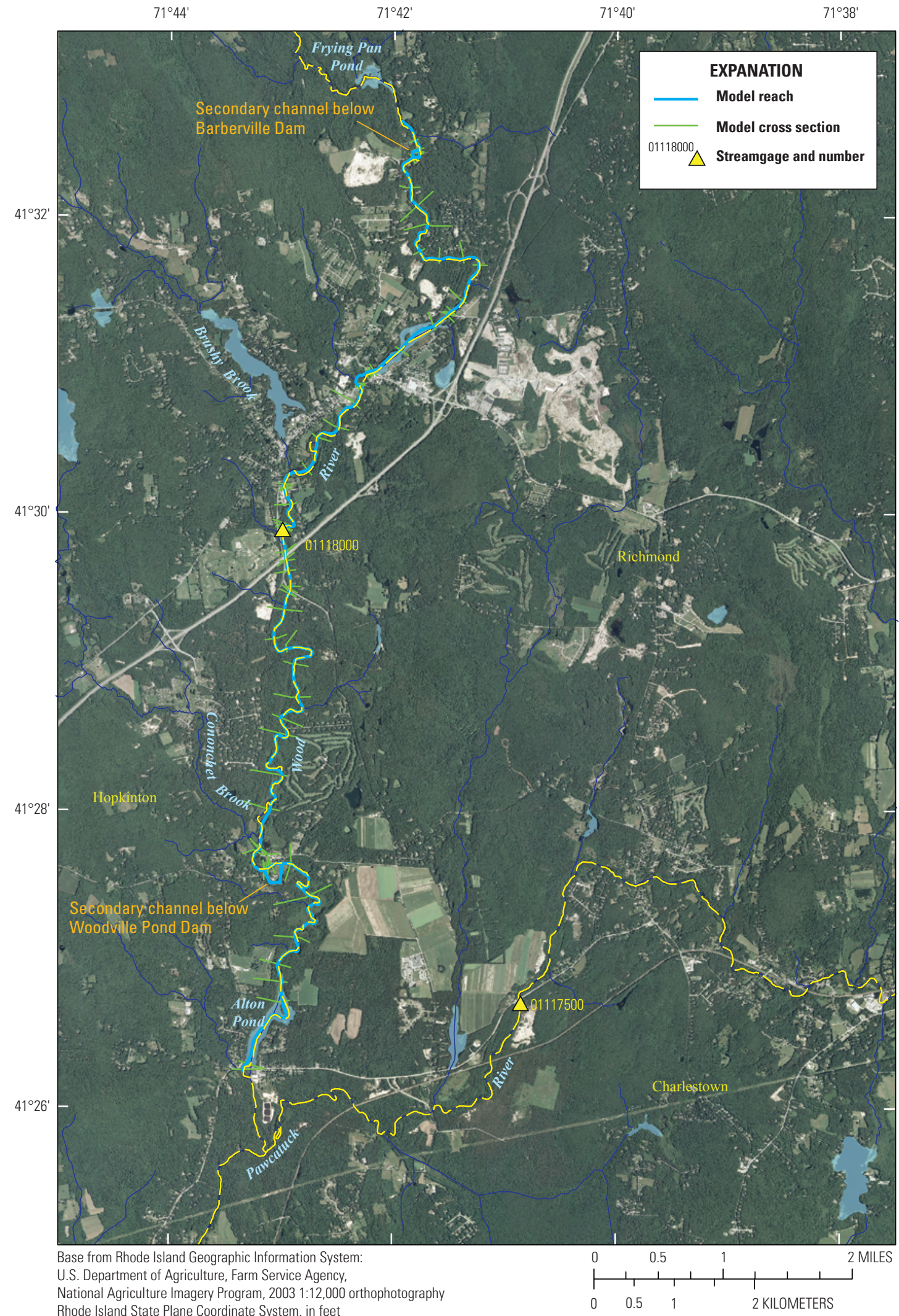

Figure 1-2. Hydraulic model reach for the Wood River, Rhode Island. 
Table 1-7. Summary of structures in the hydraulic model for the Wood River, Rhode Island.

[River station rounded to the nearest foot; AEP, annual exceedance probability; Inl Struct, in line structure; --, not applicable; Press/weir, pressure and weir flow equations; WSPRO, Water surface profile computation (Federal Highway Administration, 1990); USGS, U.S. Geological Survey]

\begin{tabular}{|c|c|c|c|c|}
\hline \multirow{2}{*}{$\begin{array}{l}\text { River station } \\
\text { (feet) }\end{array}$} & \multirow{2}{*}{ Description } & \multirow{2}{*}{ Structure type } & \multicolumn{2}{|c|}{ 1-percent AEP flow } \\
\hline & & & Road overflow & Solution type \\
\hline 3,936 & Alton Pond Dam-Church Street & Inl Struct & -- & Weir \\
\hline 17,000 & Woodville Canal powerhouse weir & Inl Struct & -- & Weir \\
\hline 17,559 & Woodville Road & Bridge & Yes & Press/weir \\
\hline 17,560 & Woodville Road (over canal) & Bridge & No & WSPRO \\
\hline 17,682 & Woodville Canal Dam & Inl Struct & -- & Weir \\
\hline 17,683 & Main channel Woodville Dam & Inl Struct & -- & Weir \\
\hline 34,272 & Switch Road-Hope Valley Road & Bridge & No & Momentum \\
\hline 35,707 & Interstate 95 & Bridge & No & $\mathrm{WSPRO}^{2}$ \\
\hline 36,895 & USGS streamgage weir & Inl Struct & -- & Weir \\
\hline 39,055 & Old Switch Road & Bridge & $\mathrm{No}^{1}$ & $\mathrm{WSPRO}^{3}$ \\
\hline 39,185 & Old Stone Dam & Inl Struct & -- & Weir \\
\hline 45,117 & Main Street (Routes 3 and 138) & Bridge & No & $\mathrm{WSPRO}^{4}$ \\
\hline 46,101 & Bridge Street & Bridge & No & WSPRO \\
\hline 46,182 & Wyoming Pond Dam & Inl Struct & -- & Weir \\
\hline 50,242 & Skunk Hill Road & Bridge & No & Energy \\
\hline 60,400 & Arcadia Canal Dam & Inl Struct & -- & Weir \\
\hline 60,740 & Arcadia Road (over canal) & Bridge & $\mathrm{No}^{1}$ & Pressure $^{3}$ \\
\hline 60,741 & Arcadia Road & Bridge & No & Pressure \\
\hline 60,788 & Barberville Dam & Inl Struct & -- & Weir \\
\hline
\end{tabular}

${ }^{1}$ Road overflow occurs at the 0.2 -percent AEP flow.

${ }^{2}$ Energy solution at the 0.2 -percent AEP flow.

${ }^{3}$ Pressure and weir flow at the 0.2-percent AEP flow.

${ }^{4}$ Pressure flow at the 0.2-percent AEP flow.

\section{Field Survey Quality Control}

At most structures that affect river conveyance such as bridges, culverts, and dams, the USGS conducted field surveys following FEMA guidelines and standards for data acquisition for flood mapping (FEMA, 2011). The USGS conducted both global positioning system (GPS) and conventional surveys for this study. The GPS surveys were conducted to establish control points at each section using Trimble $\mathrm{R} 8$ receivers that support the L1, L2, and GLONASS L2C and L5 signals. Conventional surveys were conducted to obtain stream and hydraulic-structure geometry using the control points for vertical and horizontal reference. The horizontal position is in NAD 83 using Rhode Island State Plane coordinates and vertical elevation is NAVD 88. Third order accuracy (horizontal and vertical) was maintained for all conventional survey data collected. Control for the USGS survey was established using National Geodetic Survey (NGS) monuments (benchmarks) with known horizontal and (or) vertical coordinates (table 1-8).

Continuous real-time differential corrections to the field GPS horizontal and vertical positions were made using a proprietary fixed-base station GPS network operated by KeyNetGPS, Inc. The network and associated software determines corrections for satellite signals received by the field GPS receiver for ionosphere and other atmospheric disturbances recorded at three or more of the closest fixed-base stations relative to the position of the field GPS receiver. The fixedbase station receivers continuously stream data to a central server that calculates corrections at the location of the field GPS receiver in real time. The fixed-station network in the 
Table 1-8. Comparison of U.S. Geological Survey measured coordinates and elevations to established National Geodetic Survey (NGS) benchmarks used for quality control of hydraulic model field surveys in Rhode Island.

[BM, benchmark; PID, permanent identifier; W, west; NGS, National Geodetic Survey; NAVD 88, North American Vertical Datum of 1988; NAD 83, North American Datum of 1983; WGS, World Geodetic System - minor differences with NAD 83 because of different reference ellipsoids. NAD 83 is stationary in time while WGS can shift in time but the WGS 84 and NAD 83 are intended to match; Delta, difference between established reference and surveyed coordinates or elevation; GPS, global positioning system; RMSE, root mean square error]

\begin{tabular}{|c|c|c|c|c|c|c|c|c|c|}
\hline \multirow{2}{*}{ BM PID } & \multicolumn{3}{|c|}{$\begin{array}{c}\text { Longitude } \\
\text { (decimal degrees-W) }\end{array}$} & \multicolumn{3}{|c|}{$\begin{array}{c}\text { Latitude } \\
\text { (decimal degrees) }\end{array}$} & \multicolumn{3}{|c|}{$\begin{array}{c}\text { Elevation } \\
\text { (feet NAVD 88) }\end{array}$} \\
\hline & $\begin{array}{c}\text { NGS } \\
\text { NAD } 83\end{array}$ & $\begin{array}{l}\text { Surveyed } \\
\text { WGS } 84\end{array}$ & Delta & $\begin{array}{c}\text { NGS } \\
\text { NAD } 83\end{array}$ & $\begin{array}{l}\text { Surveyed } \\
\text { WGS } 84\end{array}$ & Delta & NGS & Surveyed & Delta \\
\hline \multicolumn{10}{|c|}{ GPS-1 serial number 5034445842 (acquired November 2010) } \\
\hline LW1435 & 71.57944 & 71.57962 & -0.00018 & 41.75639 & 41.75654 & -0.00015 & 302.35 & 302.37 & -0.02 \\
\hline LW1347 & 71.56278 & 71.56279 & -0.00001 & 41.73017 & 41.73017 & 0.00000 & 202.54 & 202.51 & 0.03 \\
\hline LW1347 & 71.56278 & 71.56279 & -0.00001 & 41.73017 & 41.73017 & 0.00000 & 202.54 & 202.50 & 0.04 \\
\hline LW1063 & 71.52181 & 71.52182 & -0.00001 & 41.70901 & 41.70900 & 0.00001 & 128.69 & 128.68 & 0.01 \\
\hline LW0452 & 71.43139 & 71.43149 & -0.00010 & 41.70694 & 41.70701 & -0.00007 & 42.14 & 42.15 & -0.01 \\
\hline LW0452 & 71.43139 & 71.43149 & -0.00010 & 41.70694 & 41.70701 & -0.00007 & 42.14 & 42.10 & 0.04 \\
\hline LW0350 & 71.47083 & 71.47071 & 0.00012 & 41.71611 & 41.71599 & 0.00012 & 68.52 & 68.50 & 0.02 \\
\hline LW0452 & 71.43139 & 71.43149 & -0.00010 & 41.70667 & 41.70701 & -0.00034 & 42.14 & 42.05 & 0.09 \\
\hline LW0452 & 71.43139 & 71.43149 & -0.00010 & 41.70667 & 41.70701 & -0.00034 & 42.14 & 42.10 & 0.04 \\
\hline LW0452 & 71.43139 & 71.43149 & -0.00010 & 41.70667 & 41.70701 & -0.00034 & 42.14 & 42.09 & 0.05 \\
\hline LW0452 & 71.43139 & 71.43149 & -0.00010 & 41.70667 & 41.70701 & -0.00034 & 42.14 & 41.96 & 0.18 \\
\hline LW1352 & 71.56083 & 71.56074 & 0.00009 & 41.68556 & 41.68587 & -0.00031 & 226.19 & 226.17 & 0.02 \\
\hline LW1347 & 71.56278 & 71.56279 & -0.00001 & 41.73017 & 41.73017 & 0.00000 & 202.54 & 202.42 & 0.12 \\
\hline LW1352 & 71.56083 & 71.56074 & 0.00009 & 41.68556 & 41.68587 & -0.00031 & 226.19 & 226.07 & 0.12 \\
\hline LW1352 & 71.56083 & 71.56074 & 0.00009 & 41.68556 & 41.68587 & -0.00031 & 226.19 & 226.12 & 0.07 \\
\hline LW1351 & 71.55725 & 71.55726 & -0.00001 & 41.69186 & 41.69186 & 0.00000 & 246.14 & 246.07 & 0.07 \\
\hline LW0410 & 71.49222 & 71.49232 & -0.00010 & 41.86528 & 41.86532 & -0.00004 & 112.80 & 112.94 & -0.14 \\
\hline LW0440 & 71.43861 & 71.43884 & -0.00023 & 41.81556 & 41.81568 & -0.00012 & 53.08 & 52.90 & 0.18 \\
\hline LW0440 & 71.43861 & 71.43884 & -0.00023 & 41.81556 & 41.81568 & -0.00012 & 53.08 & 53.03 & 0.05 \\
\hline LW0440 & 71.43861 & 71.43884 & -0.00023 & 41.81556 & 41.81568 & -0.00012 & 53.08 & 52.98 & 0.10 \\
\hline LW0440 & 71.43861 & 71.43884 & -0.00023 & 41.81556 & 41.81568 & -0.00012 & 53.08 & 53.06 & 0.02 \\
\hline LW0316 & 71.38944 & 71.38976 & -0.00032 & 41.89889 & 41.89913 & -0.00024 & 64.77 & 64.75 & 0.02 \\
\hline LW0316 & 71.38944 & 71.38976 & -0.00032 & 41.89889 & 41.89913 & -0.00024 & 64.77 & 64.66 & 0.11 \\
\hline \multirow[t]{3}{*}{ LW0399 } & 71.48139 & 71.48080 & 0.00059 & 41.75528 & 41.75744 & -0.00216 & 52.15 & 52.05 & 0.10 \\
\hline & & Mean & -0.00006 & & & -0.00023 & & & 0.06 \\
\hline & & & & & & & & RMSE & 0.10 \\
\hline \multicolumn{10}{|c|}{ GPS-2 serial number 6111463172 (acquired June 2011) } \\
\hline LW0410 & 71.49222 & 71.49232 & -0.00010 & 41.86528 & 41.86532 & -0.00004 & 112.84 & 112.61 & 0.23 \\
\hline LW1347 & 71.56278 & 71.56279 & -0.00001 & 41.73017 & 41.73017 & 0.00000 & 202.54 & 202.57 & -0.03 \\
\hline LW0410 & 71.49222 & 71.49232 & -0.00010 & 41.86528 & 41.86532 & -0.00004 & 112.84 & 112.75 & 0.09 \\
\hline LW0445 & 71.47861 & 71.47897 & -0.00036 & 41.82028 & 41.82038 & -0.00010 & 211.36 & 211.51 & -0.15 \\
\hline LW0316 & 71.38944 & 71.38976 & -0.00032 & 41.89889 & 41.89913 & -0.00024 & 64.77 & 64.67 & 0.10 \\
\hline LW0745 & 71.83147 & 71.83145 & 0.00002 & 41.37751 & 41.37750 & 0.00001 & 11.58 & 11.72 & -0.14 \\
\hline LW0411 & 71.48994 & 71.48995 & -0.00001 & 41.86596 & 41.86596 & 0.00000 & 138.42 & 138.39 & 0.03 \\
\hline LW0411 & 71.48994 & 71.48995 & -0.00001 & 41.86596 & 41.86596 & 0.00000 & 138.42 & 138.56 & -0.14 \\
\hline LW0745 & 71.83147 & 71.83145 & 0.00002 & 41.37751 & 41.37750 & 0.00001 & 11.58 & 11.43 & 0.15 \\
\hline LW0452 & 71.43139 & 71.43148 & -0.00010 & 41.70667 & 41.70701 & -0.00034 & 42.14 & 42.02 & 0.12 \\
\hline LW1492 & 70.99556 & 70.99562 & -0.00007 & 41.90278 & 41.90314 & -0.00036 & 24.15 & 23.89 & 0.26 \\
\hline \multirow[t]{3}{*}{ LW0316 } & 71.38944 & 71.38976 & -0.00032 & 41.89889 & 41.89913 & -0.00024 & 64.75 & 64.65 & 0.10 \\
\hline & & Mean & -0.00011 & & & -0.00011 & & & 0.05 \\
\hline & & & & & & & & RMSE & 0.14 \\
\hline
\end{tabular}


Rhode Island region consists of five base stations: Providence, R.I. (NBC1); Fall River, Mass. (ABL1); Framingham, Mass. (KP16); Boston, Mass. (KP19); and Norwich, Conn. (MTG1). Quality-assurance GPS measurements were made at 36 NGS benchmarks with vertical datum throughout the study area. The elevation of the GPS measured BMs yielded a vertical root mean square error (RMSE) of 0.10 and $0.14 \mathrm{ft}$ for the two field GPS units, respectively.

\section{References Cited}

Ackerman, C.T., 2011, HEC-GeoRAS GIS tools for support of HEC-RAS using ArcGIS_-User's manual (ver. 4.3.93): Davis, Calif., U.S. Army Corps of Engineers, Hydrologic Engineering Center, CPD-83, 244 p.

Brunner, G.W., 2010a, HEC-RAS river analysis systemUser's manual (ver. 4.1): Davis, Calif., U.S. Army Corps of Engineers, Hydrologic Engineering Center, CPD-68, 766 p.

Brunner, G.W., 2010b, HEC-RAS river analysis systemHydraulic reference manual (ver. 4.1): Davis, Calif., U.S. Army Corps of Engineers, Hydrologic Engineering Center, CPD-69, 411 p.

FEMA - Federal Emergency Management Agency

FEMA, 2009, Flood Insurance Study_Washington County, Rhode Island: Community no. 44009CV000A, Preliminary June 1, 2009, 143 p.
FEMA, 2011, Guidelines and standards for flood hazard mapping partners, Appendix M-Data capture standards: $170 \mathrm{p}$.

Federal Highway Administration, 1990, User's manual for WSPRO-A computer model for water surface profile computations: U.S. Department of Transportation, FHWAIP-89-027, 177 p.

MOD, 2008, Updating tidal profiles for New England coastline: Report to Federal Emergency Management Agency, $41 \mathrm{p}$.

U.S. Army Corps of Engineers, 1988, Tidal flood profilesNew England coastline: Waltham, Mass., Hydraulics and Water Quality Section, New England Division, 29 p.

U.S. Interagency Advisory Committee on Water Data, 1982, Guidelines for determining flood flow frequency: Reston, Va., U.S. Geological Survey, Office of Water Data Coordination, Bulletin 17B of the Hydrology Subcommittee, $183 \mathrm{p}$.

Warner, J.C., Brunner, G.W., Wolfe, B.C., and Piper, S.S., 2010, HEC-RAS river analysis system-Applications guide (ver. 4.1): Davis, Calif., U.S. Army Corps of Engineers, Hydrologic Engineering Center, CPD-70, 351 p.

Zarriello, P.J., Ahearn, E.A., and Levin, S.B., 2012, Magnitude of flood flows for selected annual exceedance probabilities in Rhode Island, through 2010 (ver. 1.1, revised October 17, 2012): U.S. Geological Survey Scientific Investigations Report 2012-5109, 93 p. (available at http://pubs.usgs.gov/ $\operatorname{sir} / 2012 / 5109 /$.) 
Prepared by the Pembroke and Columbus Publishing Service Centers.

For more information concerning this report, contact:

Office Chief

U.S. Geological Survey

New England Water Science Center

Massachusetts-Rhode Island Office

10 Bearfoot Road

Northborough, MA 01532

dc_ma@usgs.gov

or visit our Web site at:

http://ma.water.usgs.gov 
